\title{
Crosstalk between Gut and Brain in Alzheimer's Disease: The Role of Gut Microbiota Modulation Strategies
}

\author{
Umair Shabbir ${ }^{1}{ }^{\circledR}$, Muhammad Sajid Arshad ${ }^{2}$, Aysha Sameen ${ }^{3}(1)$ and Deog-Hwan Oh ${ }^{1, *}$ \\ 1 Department of Food Science and Biotechnology, College of Agriculture and Life Sciences, \\ Kangwon National University, Chuncheon 24341, Korea; umair336@gmail.com \\ 2 Department of Food Science, Faculty of Life Sciences, Government College University, \\ Faisalabad 38000, Pakistan; msajidarshad@gcuf.edu.pk \\ 3 National Institute of Food Science and Technology, Faculty of Food, Nutrition and Home Sciences, \\ University of Agriculture, Faisalabad 38000, Pakistan; ayshasameen@uaf.edu.pk \\ * Correspondence: deoghwa@kangwon.ac.kr; Tel.: +82-33-250-6457
}

Citation: Shabbir, U.; Arshad, M.S.; Sameen, A.; Oh, D.-H. Crosstalk between Gut and Brain in Alzheimer's Disease: The Role of Gut Microbiota Modulation Strategies. Nutrients 2021, 13, 690. https:// doi.org/10.3390/nu13020690

Academic Editor: Arpana Gupta

Received: 25 January 2021

Accepted: 17 February 2021

Published: 21 February 2021

Publisher's Note: MDPI stays neutral with regard to jurisdictional claims in published maps and institutional affiliations.

Copyright: (c) 2021 by the authors. Licensee MDPI, Basel, Switzerland. This article is an open access article distributed under the terms and conditions of the Creative Commons Attribution (CC BY) license (https:// creativecommons.org/licenses/by/ $4.0 /)$.

\begin{abstract}
The gut microbiota (GM) represents a diverse and dynamic population of microorganisms and about 100 trillion symbiotic microbial cells that dwell in the gastrointestinal tract. Studies suggest that the GM can influence the health of the host, and several factors can modify the GM composition, such as diet, drug intake, lifestyle, and geographical locations. Gut dysbiosis can affect brain immune homeostasis through the microbiota-gut-brain axis and can play a key role in the pathogenesis of neurodegenerative diseases, including dementia and Alzheimer's disease (AD). The relationship between gut dysbiosis and $\mathrm{AD}$ is still elusive, but emerging evidence suggests that it can enhance the secretion of lipopolysaccharides and amyloids that may disturb intestinal permeability and the blood-brain barrier. In addition, it can promote the hallmarks of AD, such as oxidative stress, neuroinflammation, amyloid-beta formation, insulin resistance, and ultimately the causation of neural death. Poor dietary habits and aging, along with inflammatory responses due to dysbiosis, may contribute to the pathogenesis of AD. Thus, GM modulation through diet, probiotics, or fecal microbiota transplantation could represent potential therapeutics in AD. In this review, we discuss the role of GM dysbiosis in AD and potential therapeutic strategies to modulate GM in AD.
\end{abstract}

Keywords: gut dysbiosis; microbial metabolites; diet; probiotics; neurodegenerative diseases

\section{Introduction}

The human body hosts trillions of microorganisms, including bacteria, fungi, archaea, and viruses. These symbiotic microorganisms can be beneficial, neutral or detrimental to the host and play regulatory functions in both health and disease. They can be found in the urogenital organs, respiratory tract, skin surface, and gastrointestinal tract (GIT). About 95\% of the symbiotic microorganisms of the human microbiome reside in the gut [1]. Intricate ecological colonies of microorganisms dwell in the GIT and are collectively known as the gut microbiota (GM) [2,3]. The GM comprises mainly bacteria, fungi, bacteriophages, archaea, protozoa, and eukaryotic viruses and about 100 trillion microorganisms are harbored in the human GIT [4,5]. Firmicutes, Bacteroides, Proteobacteria and Actinobacteria represent the major bacteria of the gut [6], followed by Bifidobacterium, Clostridium, Eubacterium, Peptococcus, Provetella, etc. [7]. The small intestine consists of various types of bacteria, with content levels ranging from $10^{4}$ bacteria $/ \mathrm{mL}$ to $10^{6}-10^{7}$ bacteria $/ \mathrm{mL}$ at the ileocecal junction, while the large intestine contains most of the non-spore forming bacteria (from $10^{11}-10^{12}$ bacteria/g content) [8]. The population of GM is different for each person and is composed of various bacterial species. Furthermore, the composition of the GM is different at different stages of life. In older age individuals, increased Firmicutes and Bacteroidetes populations can be observed as compared to in younger individuals [9]. The GM is involved in metabolic processes and defense mechanisms and represents a dynamic and diverse 
population which impacts on the health and disease of the host. The GM develops the immune system in the intestinal mucosa and protects the host from carcinogens by releasing short-chain fatty acids (SCFA) [3]. Alterations of the GM community are referred to as dysbiosis $[4,10]$, and these can lead to metabolic disorders. However, recent studies have proposed that this can also affect the central nervous system (CNS) because of the microbiota-gut-brain axis (MGBX) [11-13]. The brain regulates the secretory and sensory functions of the gut, and the connection between the gut and brain is interceded by physiological channels such as the autonomic nervous system, neuroendocrine system, neuroimmune pathways, and signaling molecules produced by the GM [14]. However, the actual mechanism and relationship between neural dysfunction and gut dysbiosis is elusive [15]. Emerging evidence suggests that gut dysbiosis can cause neurocognitive disorders such as schizophrenia, depression, bipolar disorder, anxiety, post-traumatic stress disorder, obsessive-compulsive disorder, and dementia, as well as the psychological and behavioral symptoms of dementia (Table 1) [12]. Additionally, metabolic syndromes and gut dysbiosis also contribute to Alzheimer's disease (AD) and effect memory, learning, and hippocampal plasticity [16]. Diet, probiotics, and other therapeutic strategies have positive effects on GM modulation that may be helpful in the treatment of $\mathrm{AD}$, as these factors alter the composition of the GM and have a positive impact on the host, improving the health status of the gut and body overall [3]. This review summarizes the role of GM dysbiosis, microbial metabolites, and metabolic impairment in AD. Additionally, the role of potential therapeutic strategies in modulating the GM composition and techniques to characterize the gut microbiome are also highlighted.

Table 1. Changes in microbiome occur during several mental conditions and their related findings.

\begin{tabular}{|c|c|c|c|c|}
\hline Condition & Study & Change in Microbiome & Findings & Reference \\
\hline \multirow{3}{*}{ Depression } & $\begin{array}{l}\text { Human } \\
(n=90)\end{array}$ & $\begin{array}{c}\uparrow \text { Phylum Bacteroidetes, classes } \\
\text { Gammaproteobacteria and Bacteroidia, order } \\
\text { Bacteroidales, and genera } \\
\text { Flavonifractor and Sellimonas. } \downarrow \text { Phylum Firmicutes, } \\
\text { class Clostridia, order Clostridiales, family } \\
\text { Ruminococcaceae (Subdoligranulum, } \\
\text { Faecalibacterium, Ruminococcus 1, and } \\
\text { (Eubacterium) coprostanoligenes), and family } \\
\text { Christensenellaceae (Christensenellaceae R7 group). }\end{array}$ & $\begin{array}{c}\text { Low levels of SCFA, } \\
\text { anti-inflammatory, and } \\
\text { butyrate-producing bacteria may } \\
\text { link the GM and the low-grade and } \\
\text { chronic inflammation. }\end{array}$ & [17] \\
\hline & $\begin{array}{l}\text { Human } \\
(n=16)\end{array}$ & $\begin{array}{c}\text { Depression showed a positive correlation with } \\
\text { Paraprevotella, negative correlations with } \\
\text { Clostridiales, Clostridia, Firmicutes, } \\
\text { and the RF32 order. }\end{array}$ & $\begin{array}{l}\text { Intestinal inflammation and } \\
\text { integrity markers found to be } \\
\text { related to the response to treatment } \\
\text { in patients with symptom severity } \\
\text { and major depressive disorder. }\end{array}$ & [18] \\
\hline & $\begin{array}{l}\text { Human } \\
(n=111)\end{array}$ & $\begin{array}{l}\text { Clostridiales order, Ruminococcaceae family } \\
\text { (Clostridium symbiosum and Coprococcus catus) } \\
\text { variably differentiated depression severity strata. }\end{array}$ & $\begin{array}{l}\text { Coprococcus catus specifically found } \\
\text { to be a contributor to psychiatric } \\
\text { functioning. }\end{array}$ & [19] \\
\hline \multirow[t]{2}{*}{ Schizophrenia } & $\begin{array}{l}\text { Human } \\
(n=26)\end{array}$ & $\begin{array}{c}\uparrow \text { Proteobacteria, Chaetomium } \\
\downarrow \text { Faecalibacterium, Lachnospiraceae, } \\
\text { and Trichoderma. }\end{array}$ & $\begin{array}{l}\text { Faecalibacterium and Genera } \\
\text { Lachnospiraceae allow } \\
\text { opportunistic pathogens such as } \\
\text { Protobacteria to translocate and are } \\
\text { involved in CD4 cell differentiation } \\
\text { and can increase gut TH17 cells that } \\
\text { can penetrate through the BBB and } \\
\text { induce abnormal behavior. }\end{array}$ & [20] \\
\hline & Animal & $\begin{array}{c}\uparrow \text { Lactobacillus and Bifidobacterium. } \\
\downarrow \downarrow \text { Akkermansia }\end{array}$ & $\begin{array}{l}\text { Administration of Inulin } \\
\text { modulated GM decreased 5-HT } \\
\text { and inflammatory cytokines and } \\
\text { enhanced BDNF though the MGBX } \\
\text { and ameliorated schizophrenia. }\end{array}$ & [21] \\
\hline
\end{tabular}


Table 1. Cont.

\begin{tabular}{|c|c|c|c|c|}
\hline Condition & Study & Change in Microbiome & Findings & Reference \\
\hline \multirow{2}{*}{$\begin{array}{l}\text { Bipolar } \\
\text { disorder }\end{array}$} & $\begin{array}{l}\text { Human } \\
(n=36)\end{array}$ & $\begin{array}{c}\downarrow \text { Bifidobacteria to Enterobacteriaceae } \\
\text { ratio } \uparrow \text { Enterobacter spp, Faecalibacterium prausnitzii, } \\
\text { Clostridium Cluster IV, Atopobium Cluster, and } \\
\text { Bacteroides-Prevotella group. }\end{array}$ & $\begin{array}{l}\text { Brain-gut coefficient of balance } \\
\left.\text { (B-G } G_{C B}\right) \text { was used as a new concept. }\end{array}$ & [22] \\
\hline & $\begin{array}{l}\text { Human } \\
(n=32)\end{array}$ & $\begin{array}{c}\uparrow \text { Actinobacteria Coriobacteriia } \\
\downarrow \text { Faecalibacterium and Ruminococcaceae. }\end{array}$ & $\begin{array}{c}\text { Actinobacteria and Coriobacteriia take } \\
\text { part in lipid metabolism correlating } \\
\text { with cholesterol levels, found in } \\
\text { bipolar patients. }\end{array}$ & [23] \\
\hline Anxiety & $\begin{array}{l}\text { Human } \\
(n=9)\end{array}$ & $\begin{array}{c}\downarrow \text { Microbial richness and diversity. } \\
\uparrow \text { Escherichia-Shigella, Fusobacterium, and } \\
\text { Ruminococcus gnavus. }\end{array}$ & $\begin{array}{l}\text { Enhanced gut permeability due to } \\
\text { decrease in SCFA producing } \\
\text { bacteria. Increase in the abundance } \\
\text { of Escherichia-Shigella, Ruminococcus } \\
\text { gnavus, and Fusobacterium bacteria } \\
\text { may support systemic } \\
\text { inflammation and degrade mucins. }\end{array}$ & {$[24]$} \\
\hline \multirow{2}{*}{$\begin{array}{l}\text { Post-traumatic } \\
\text { stress disorder }\end{array}$} & Animal & $\begin{array}{l}\text { Alteration in Bacteroidetes, Firmicutes, } \\
\text { Proteobacteria, and Cyanobacteria levels. }\end{array}$ & $\begin{array}{l}\text { Changes in levels of } \\
\text { neurotransmitters such as 5-HT, } \\
\text { dopamine, and norepinephrine } \\
\text { were observed in stressed rats. }\end{array}$ & [25] \\
\hline & $\begin{array}{l}\text { Human } \\
(n=93)\end{array}$ & $\begin{array}{c}\uparrow \text { Escherichia/Shigella and Enterococcus } \\
\downarrow \text { Autochthonous taxa, Lachnospiraceaeae } \\
\text { and Ruminococcaceae. }\end{array}$ & $\begin{array}{l}\text { Escherichia/Shigella and Enterococcus } \\
\text { linked with poor cognition, and } \\
\text { higher levels of lipopolysaccharides } \\
\text { are linked with neuroinflammation } \\
\text { through MGBX. }\end{array}$ & [26] \\
\hline $\begin{array}{l}\text { Obsessive- } \\
\text { compulsive } \\
\text { disorder }\end{array}$ & $\begin{array}{l}\text { Human } \\
(n=43)\end{array}$ & $\begin{array}{c}\downarrow \text { species richness/evenness (Inverse Simpson, } \\
\alpha \text {-diversity), relative abundance of butyrate } \\
\text { producing genera (Anaerostipes, Odoribacter, } \\
\text { and Oscillospira). }\end{array}$ & $\begin{array}{l}\text { Mean C-reactive protein, but not } \\
\text { IL-6 and TNF- } \alpha \text {, was increased in } \\
\text { the patients. C-reactive protein } \\
\text { exhibited mild to strong linkage } \\
\text { with psychiatric symptomatology. }\end{array}$ & [27] \\
\hline \multirow[t]{2}{*}{ Dementia } & $\begin{array}{l}\text { Human } \\
(n=128)\end{array}$ & $\begin{array}{c}\uparrow \text { Enterotype I and III bacteria were associated } \\
\text { with dementia. }\end{array}$ & $\begin{array}{l}\text { Serum triglycerides, serum } \\
\text { C-reactive protein, and markers of } \\
\text { insulin resistance were found in } \\
\text { subjects. Fecal lactic acid and } \\
\text { ammonia were linked to dementia. }\end{array}$ & {$[28,29]$} \\
\hline & $\begin{array}{l}\text { Human } \\
(n=77)\end{array}$ & $\begin{array}{c}\downarrow \text { Clostridia and its phylum Firmicutes and the } \\
\text { Ruminococcus, Ruminococcaceae, Clostridiales at } \\
\text { order, family and genus levels. }\end{array}$ & $\begin{array}{l}\text { Decrease in SCFA producing } \\
\text { bacteria and indole-3-pyruvic acid } \\
\text { was recognized as a signature for } \\
\text { prediction and discrimination of AD. }\end{array}$ & {$[30]$} \\
\hline
\end{tabular}

$\uparrow:$ Higher, $\downarrow$ : Lower, AD: Alzheimer's disease, BDNF: brain-derived neurotrophic factor, GM: gut microbiota, BBB: blood-brain barrier, MGBX: microbiota-gut-brain axis, 5-HT: 5-hydroxytryptamine, SCFA: short-chain fatty acids, IL: interleukin, TNF- $\alpha$ : tumor necrosis factor- $\alpha$. B-G $\mathrm{G}_{\mathrm{CB}}$ : the ratio of (oxygenated hemoglobin)/(Bifidobacteria to Enterobacteriaceae ratio) to analyze the relationship between brain function and GM. n: number of total subjects in the study but the columns of GM and findings are only showing the data of diseased ones.

\section{Impact of GM and Their Metabolites on the Brain}

During metabolic processes, the GM can produce several bioactive metabolites that can enter into the bloodstream via absorption into enterohepatic circulation [4]. Metabolites linked to the phenotype of a disease can be recognized by nuclear magnetic resonance (NMR) and mass spectrometry-based metabolomics of body fluids such as urine, feces, or plasma. This makes it possible to carry out joint analyses of the host phenotypes, metabolome, and microbiome to identify mechanistic links [31]. The GM metabolizes a plethora of neurotransmitters and neuromodulators (such as short-chain fatty acids (SCFA), gamma-aminobutyric acid, acetylcholine, dopamine, glutamate, and serotonin) [32-34]. Microbial species such as Saccharomyces, Bacillus, Lactobacillus, Escherichia, and Bifidobacterium are known to produce these types of neurotransmitters [33]. Preliminary human 
studies have revealed that bacterial-based interventions can also change neurotransmitter levels involved in synaptic plasticity (including brain-derived neurotrophic factor), and regulate the activity of $\mathrm{N}$-methyl-d-aspartate and serotonin receptors [34]. Impairment of the GM composition or their metabolites modulates the gut-brain axis [33] and regulates cognition, memory, mood, and social behavior $[35,36]$. Moreover, dysbiosis may result in the formation of toxic misfolded proteins with a $\beta$-sheet conformation that promotes loss of synaptic connections, cellular cell dysfunction, and neurodegeneration [37]. The pathways involved in MGBX are illustrated in Figure 1. Moreover, some of the major microbial metabolites (neurotransmitters) and their role in brain health are exhibited in Table 2.

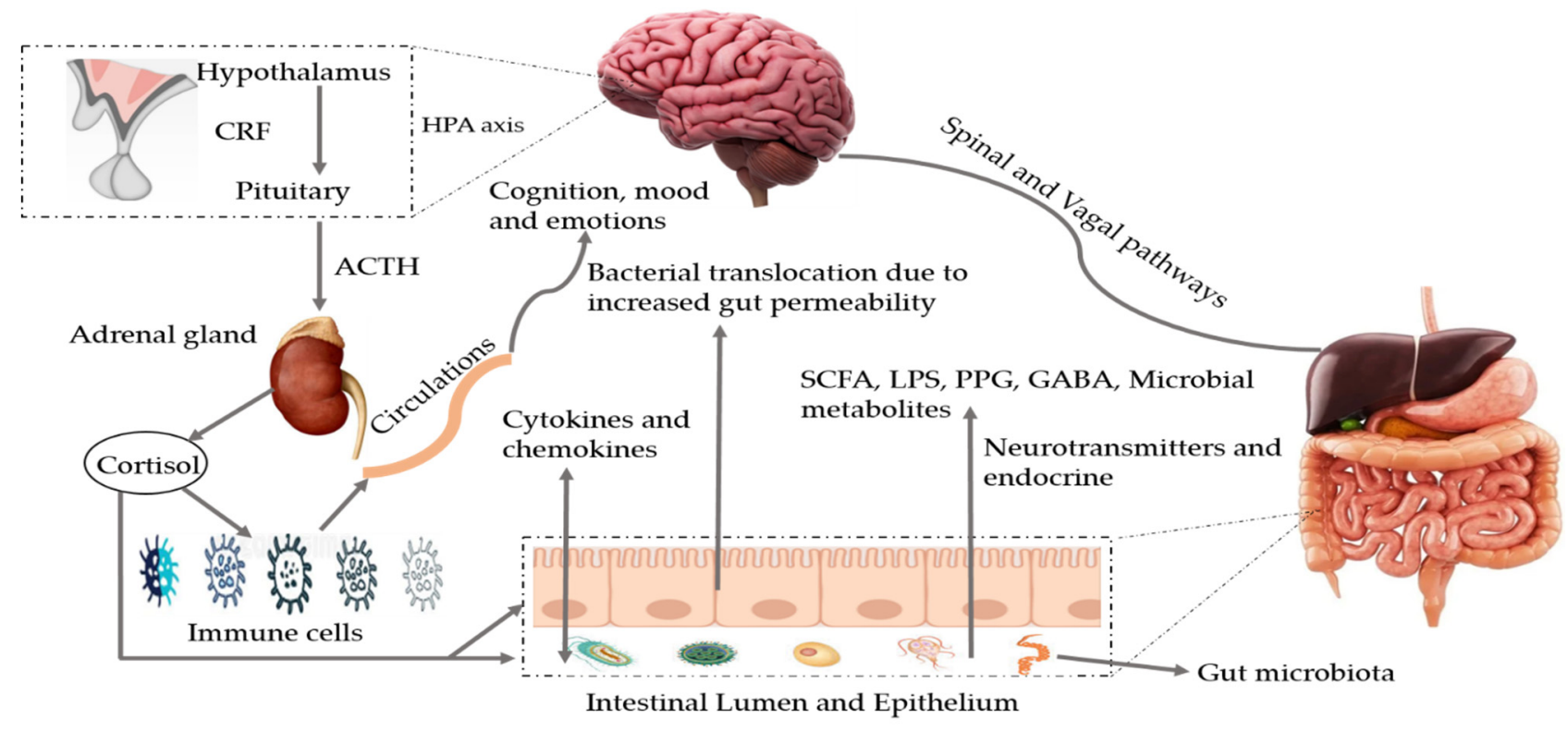

Figure 1. Bidirectional pathways involved in the communication between the gut microbiota and the brain (MGBX). They communicate through vagal and spinal nerves. SCFA, LPS, PPG, GABA, microbial metabolites, other neurotransmitters and endocrine cells are also involved. Dysbiosis can be caused by stress that may alter tryptophan levels, SCFA levels, the immune system, and gut permeability. Additionally, release of cytokines and chemokines (IL-6, IL-1 $\beta$, IL-8) can lead to neuroinflammation and activation of HPA axis. SCFA: short-chain fatty acids, LPS: lipopolysaccharides, PPG: peptidoglycans, GABA: gama-aminobutyric acid, HPA axis: hypothalamic-pituitary-adrenal axis, CRF: corticotropinreleasing factor, ACTH: adrenocorticotropic hormone. 
Table 2. Neurotransmitters produced by gut microbiota and their role in brain function.

\begin{tabular}{|c|c|c|c|c|}
\hline Gut Microbiota & Metabolites & Study & Association in Brain Function & References \\
\hline Lactobacillus, Bifidobacterium & GABA & $\begin{array}{l}\text { Human/animal } \\
\text { metagenomic }\end{array}$ & $\begin{array}{l}\text { Main inhibitory neurotransmitter of the CNS and a potential } \\
\text { mediator between bacterial cells and the host. Regulates depression, } \\
\text { anxiety, behavioral and cognitive functions. }\end{array}$ & {$[38,39]$} \\
\hline $\begin{array}{l}\text { Bifidobacterium longum, Clostridium symbiosum, } \\
\text { Faecalibacterium prausnitzii, Lactobacillus fermentum }\end{array}$ & SCFA & $\begin{array}{l}\text { Human/animal } \\
\text { metagenomic }\end{array}$ & $\begin{array}{l}\text { Regulate neuro-immunoendocrine function, reduce inflammation, } \\
\text { promote the synthesis and secretion of neurotransmitters, hormones } \\
\text { and suppress permeability of the blood-brain barrier. }\end{array}$ & [42-44] \\
\hline Lactobacillus, Escherichia, Streptococcus, Lactococcus, Bacillus & Dopamine & $\begin{array}{l}\text { Human/animal } \\
\text { metagenomic }\end{array}$ & $\begin{array}{c}\text { Protects neuron loss, improves motor deficits, cognition, reduced } \\
\text { stress and anxiety. }\end{array}$ & [45-47] \\
\hline $\begin{array}{c}\text { Escherichia coli, Morganella morganii, Lactobacillus vaginalis, } \\
\text { Enterobacter aerogenes }\end{array}$ & Histamine & $\begin{array}{l}\text { Human/animal } \\
\text { metagenomic }\end{array}$ & Regulates depression-like behaviors and impaired sleep-wake cycle. & [48-50] \\
\hline $\begin{array}{c}\text { Coryneform, Bacteroides vulgatus, Campylobacter jejuni, } \\
\text { Lactobacillus }\end{array}$ & Glutamate & $\begin{array}{l}\text { Human/animal } \\
\text { metagenomic }\end{array}$ & $\begin{array}{l}\text { Play role in molecular mechanism of learning, memory, and } \\
\text { synaptic plasticity. }\end{array}$ & [51] \\
\hline Lactobacillus, Bacillus & Acetylcholine & Animal metagenomic & $\begin{array}{c}\text { Memory, emotional personality, self-care ability, cognition, and } \\
\text { social life ability. }\end{array}$ & {$[52,53]$} \\
\hline
\end{tabular}

GABA: gamma-aminobutyric acid, CNS: central nervous system, SCFA: short-chain fatty acids, 5-HT: 5-hydroxytryptamine. 


\section{Alzheimer's Disease}

Dementia is a group of symptoms or a syndrome that causes deterioration in memory, behavior, thinking, ability to perform daily activities, judgement, and language. Dementia generally affects the elderly people but is not classified as a normal part of aging [54]. Among different kinds of dementia, AD is the most common [55], and it contributes to $60-80 \%$ of dementia cases [56]. It is one of the rapidly growing brain diseases [13] and it has been reported that $\mathrm{AD}$ and other types of dementia represent the 5th most prominent reason for deaths around the globe. Around 50 million people suffer from dementia, and this is expected to double by 2030, and triple by 2050 . Every year, approximately 10 million additional cases are reported worldwide [54,57]. In the early stages of $\mathrm{AD}$, people may suffer from memory lapses such as forgetting familiar locations and words, while the middle-stage is the longest stage that can last for years and the person may become angry or frustrated, confused, and act unpredictably. In the last stage, individuals lose the ability to carry on conversations, respond to their environment, and ultimately lose control of movement. As cognitive and memory conditions continue to be exacerbated, individuals require extensive care due to significant personality changes [54,56]. Various immune-inflammatory variations have been found in patients with $\mathrm{AD}$ and mild cognitive impairment (MCI), including raised levels of pro-inflammatory cytokines and activated microglia that allow crosstalk between the peripheral and central immune systems [58]. The major hallmarks of $\mathrm{AD}$ are as follows: development of amyloid beta $(\mathrm{A} \beta)$ plaques $(\mathrm{A} \beta$ peptides and $A \beta$-oligomers) and neurofibrillary tangles in the nerve cells [59]; elevated generation of reactive oxygen species leads to neuroinflammation and cell death. Additionally, vascular abnormalities and mitochondrial damage also contribute to the pathogenesis of $\mathrm{AD}[60,61]$.

\section{Metabolic Impairment and AD}

The GM may contribute to metabolic health, but dysbiosis in GM composition triggers metabolic syndrome. Metabolic syndrome is a combination of abnormalities contributing to different diseases such as malnutrition, non-alcoholic liver disease, obesity, cardio-metabolic diseases and type-2 diabetes $[4,62,63]$. Deficiency of SIRT3, known as a mitochondrial deacetylase, is a significant cause of metabolic syndrome. SIRT3 regulates the functioning of critical mitochondrial proteins by deacetylation [64,65]. Tyagi et al. [66] stated that deficiency of SIRT3 increases the formation of amyloid plaques and induces neuroinflammation in the brain. They crossed SIRT3 ${ }^{-/-}$mice with APP/PSI mice (doubletransgenic mouse models of AD expressing a chimeric mouse/human amyloid precursor protein and containing the L166P mutation, both directed to the CNS [67]) and generated APP/PS1/SIRT3 ${ }^{-/-}$mice with metabolic syndrome and amyloid pathology. Aggravation of glucose intolerance, insulin resistance, deposits of $A \beta$, and hallmarks of neuroinflammation such as tumor necrosis factor (TNF)- $\alpha$, interleukin (IL)- $1 \beta$, and cyclooxygenase- 2 were observed in the generated mice. Additionally, activated and proliferated microglial cells were also reported. Thus, hypothetically, metabolic syndrome and the induced amyloid pathology may interact with age related disorders such as diabetes, cardiovascular diseases, obesity, and hypertension and coexist with AD. Additionally, Gupta et al. [68] revealed that type-2 diabetes mellitus contributes to the pathophysiology of AD. Thomas et al. [69] agreed with this and stated that studied diabetic subjects $(n=69)$ suffered from at least $1 \mathrm{AD}$ risk factor (e.g., cognitive decline, $\mathrm{A} \beta$ deposition, hyperphosphorylated tau, and genetic susceptibility). On the other hand, obesity is also associated with morphological and functional impairment in mitochondria that initiate insulin resistance (responsible for tau hyperphosphorylation and $\mathrm{A} \beta$ aggregation) peripheral inflammation, memory deficits, and oxidative stress that increase the risk of $\mathrm{AD}$ [70-72]. Cuomo et al. [73] disclosed that PCR and NMR analyses showed that Helicobacter pylori could potentially modulate AD, type-2 diabetes, cardio-metabolic disease, and obesity. Helicobacter pylori induces high levels of amino acids and activates the mammalian target of rapamycin complex 1 (regulates the host's metabolism) and branched-chain amino acids. Furthermore, Helicobacter 
pylori toxin VacA resides within the mitochondria, contributing to the depletion of ATP, oxidative stress, and causes fragmentation of these organelles that induces autophagy and endure bacterial colonization of gastric mucosa [74]. It also modulates the inflammation of hyperphosphorylation of tau proteins and stimulates $A \beta$ formation.

\section{GM Dysbiosis and AD}

The GM has various links to inflammatory and metabolic pathways. Dysbiosis affects the synthesis of signaling proteins that influence metabolic processes related to $\mathrm{AD}$ progression [15]. Aging alters the GM composition (high abundance of pro-inflammatory bacteria than anti-inflammatory bacteria) and induces local systematic inflammation that causes impairment in the permeability of the GIT and blood-brain barrier function [3]. Peptostreptococcaceae, Clostridiaceae, Bifidobacteriaceae, Turicibacteraceae, Mogibacteriaceae, and Ruminococcaceae families were found to be less abundant as compared to Bacteroidaceae, Gemellaceae, and Rikenellaceae families in AD participants [75]. More specifically, it has been stated that dysbiosis contributes to the enhancement of pro-inflammatory bacteria (such as Verrucomicrobia, Escerchia/Shigella, Proteobacteria, and Pseudomonas aeruginosa) and decreases the abundance of anti-inflammatory bacteria (such as Eubacterium hallii, Bacillus fragilis, Bacteroides fragilis, Eubacterium rectale, Faecalibacterium prausnitzii, and Bifidobacterium), potentially promoting neuroinflammation and worsening the formation of $\mathrm{A} \beta$ plaques [76]. Decreases in microbial diversity have been reported in a microbiome study of $\mathrm{AD}$ and $\mathrm{MCI}$ human patients, with progressive growth of Enterobacteriaceae, Enterobacteriales, and Gammaproteobacteria being observed in comparison to controls. Moreover, enhanced biosynthesis and glycan metabolism, decreases in immune system-related pathways, and decreases the abundance of Ruminococcaceae, Lachnospiraceae, Firmicutes, and Clostridiaceae were also noted in patients [77]. On the other hand, Lee et al. [78] revealed that a transgenic murine model of $\mathrm{AD}$ showed significant changes in phyla (e.g., Bacteroidetes and Firmicutes), while an increase in Clostridium leptum group was also observed [79]. Additionally, dysbiosis may promote AD symptoms, such as oxidative stress and insulin resistance [11]. Hypothetically, it has been stated that the GM might modulate the oxidative state of the CNS through the produced metabolites. Suppressed levels of butyrate could enhance mitochondrial dysfunction resulting in the production of reactive oxygen species [80]. Cerovic et al. [81] stated that gut dysbiosis leads to both central and peripheral pathological events that could possibly increase the risk of AD. Dysbiosis in 5xFAD mice was associated with the progression of the CCAAT/enhancer binding protein $\beta /$ asparagine endopeptidase pathway that mediated AD pathology through cleaving both $\mathrm{A} \beta$ precursor and Tau proteins [82]. In a recent study, Li et al. [83] used RNA sequencing, Y maze, transcriptome sequencing, Gene Expression Omnibus, and quantitative reversetranscriptase PCR techniques for APPswe $/ \mathrm{PS}^{\Delta \mathrm{E} 9}$ transgenic mice and wild-type mice to examine the role of dysbiosis in AD. They found a significantly different composition of GM, decreased cognitive ability, and increased amyloid formation. Microbiota-mediated intestinal and systemic immune aberrations trigger the pathogenesis of AD in ADLPAPT mice [84]. Thus, it can be concluded that impairment of the GM is correlated with decreases in cognitive function and might play role in the enhancement of the amyloid deposition via stimulating the mitogen-activated protein kinase signaling pathways (these control a wide range of cellular processes, such as apoptosis, differentiation, proliferation, and stress responses [85]) in the brain. Taken together, the possible role of gut dysbiosis in contributing to neurodegeneration and AD is illustrated in Figure 2. 


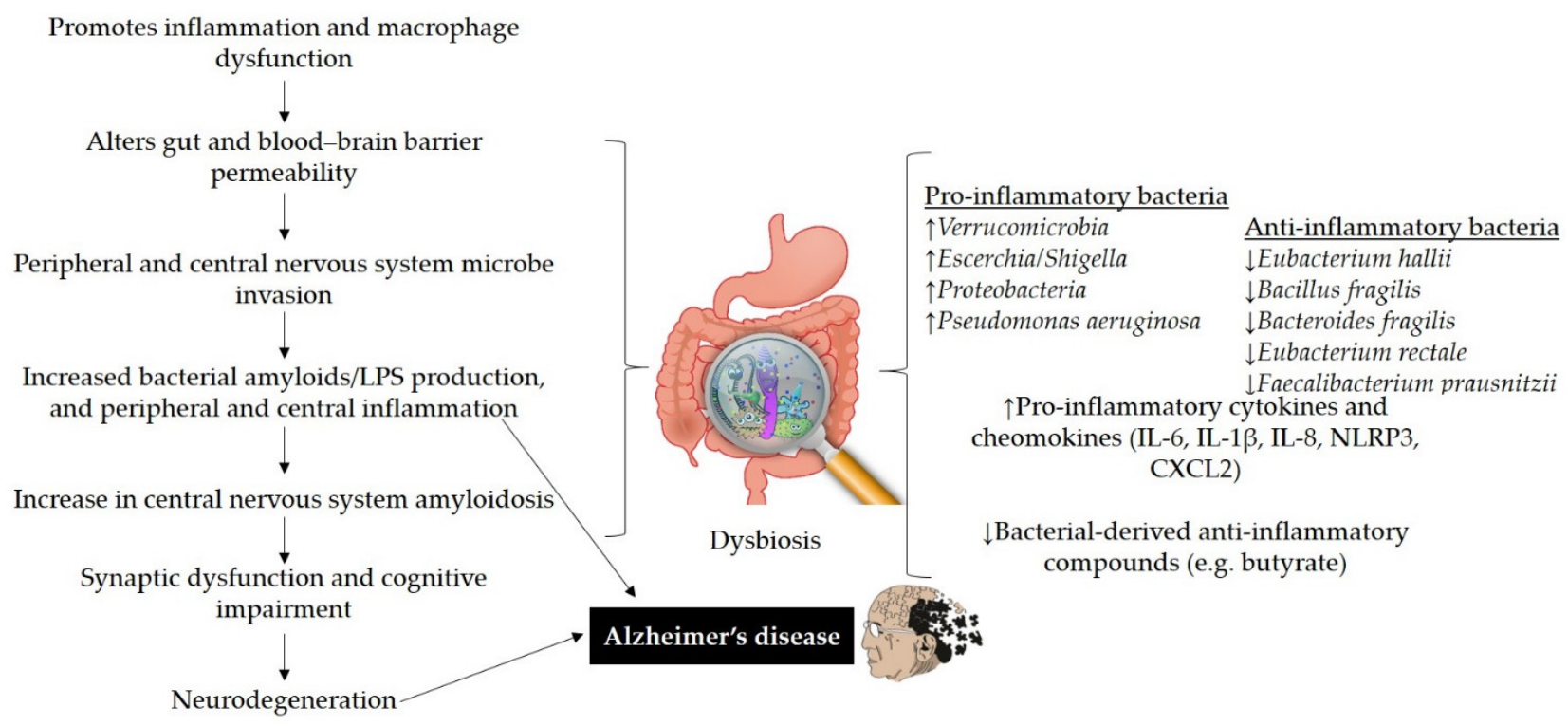

Figure 2. The possible role of gut dysbiosis in neurodegeneration and Alzheimer's disease. Disturbance in gut homeostasis impairs gut permeability due to the action of pro-inflammatory bacteria that produce bacterial amyloids/LPS and cause macrophage dysfunction. Amyloids and LPS can increase inflammatory cytokines (IL-6, IL-1 $\beta$, IL-8, NLRP3, CXCL2). Impairment in gut and blood-brain barrier may lead to the deposition of $A \beta$ fibrils in the brain and can contribute to AD pathogenesis. LPS: lipopolysaccharides, IL: interleukin, NLRP3: nod-like receptor protein 3, CXCL2: C-X-C motif chemokine ligand 2.

\section{Bacterial Amyloids and Lipopolysaccharides in AD}

Amyloids are unique proteins with self-aggregation properties, and their accumulation can cause cellular dysfunction [86]. Initiation of $A \beta$ in the brain is elusive, however, different in vitro and in vivo studies have claimed that amyloids produced by GM may cross-seed A $\beta$ deposition [87]. Bacterial strains, such as Escherichia coli, Bacillus subtilis, Salmonella Typhimurium, Pseudomonas fluorescens, Staphylococcus aureus, etc., are considered to produce amyloids. These strains produce curli, TasA, CsgA, FapC, phenol soluble modulins, etc., amyloids that promote the misfolding of $\mathrm{A} \beta$ fibrils and oligomers. The production of amyloid proteins helps bacterial cells to bind to each other and form biofilms to resist destruction by immune or physical factors [88]. It has been documented that bacterial amyloids are different from the amyloids in the brain in terms of their primary structure, but share similarities in their tertiary structure [89]. Exposure to bacterial amyloid proteins in the gut may cause priming of the immune system that, in turn, increases the immune responses to the endogenous production of neural amyloids in the CNS [88,90]. Bacterial amyloids, through molecular mimicry, may act as prion proteins that evoke cross-seeding in which the amyloidogenic protein causes the production of another protein, such as a host protein with a different primary structure, to adopt the pathogenic $\beta$-sheet structure [88]. Osorio et al. [91] proposed that amyloids are antigens that generate a defensive response to $\mathrm{A} \beta$ deposition in order to suppress danger signals. CsgA shares dissimilarity in sequences with $\mathrm{A} \beta_{42}$ but is similar in triggering $\mathrm{AD}$-related pathogenic effects and promoting cerebral plaque deposition [81]. In a recent study, Javed et al. [92] claimed that FapCS favorably bound with $A \beta$, showed a catalytic capacity in seeding peptide amyloidosis, impaired cognitive performance, and behavior pathology in vitro, in silico and in a zebrafish AD model. Additionally, phenol soluble modulins contain cross- $\alpha$ structure and form cross- $\beta$ fibrils associated with AD [93]. Sampson et al. [86] exhibited that curli-producing Escherichia coli, enhance the pathology of amyloid $\alpha$-synuclein (involved in the progression of AD, dementia and Parkinson's disease [94]) in the gut and brain of mice. In a similar study, increased expression of Toll-like receptor 2, and pro-inflammatory mediators IL-6 and TNF, in association with astrogliosis and microgliosis, were also observed in rats exposed to 
the curli amyloid. Cattaneo et al. [76] stated that amyloidosis positive patients exhibited higher serum levels of IL-1 $\beta$, IL-6, C-X-C motif chemokine ligand, and nod-like receptor protein 3 , and lower serum levels of anti-inflammatory cytokine IL-10.

Lipopolysaccharides (LPS) mainly produced by Gram-negative bacteria (Proteobacteria and Bacteroidetes: pro-inflammatory bacteria) can induce inflammation and disrupt the blood-brain barrier function [95]. A plethora of in vivo and in vitro studies suggested that LPS activate several intracellular molecules that change the expression of different inflammatory mediators and in turn, contribute or initiate the progression/development of neurodegeneration [96]. Khan et al. [97] stated that LPS activate the Toll-like receptor 4 and cause the epithelial and intestinal-wall inflammation that results in leaky gut. LPS also activate astrocyte and microglial cells in the GIT that secrete pro-inflammatory cytokines, those later gain entry to the bloodstream through leaky gut. This serum LPS cause disruption in the blood-brain barrier and may enter the brain and reactivate microglia, and astrocytes, and various amyloid genic and inflammatory pathways. Increased inflammatory cytokines and nuclear factor kappa B (NF- $\mathrm{kB}$ ) leads to an increase in amyloid precursor protein and $A \beta$ protein cleavage and accumulation that causes the death of neurons and $A D$ development. Moreover, LPS promote $A \beta_{42}$ fibrillogenesis which triggers the formation of $A \beta_{1-40 / 42}$ plaques in the white and grey matter of $\mathrm{AD}$ brains [98]. The abundance of LPS was also observed in the hippocampus and in the neocortex [99], and in the lysates from the superior temporal lobe of AD brains [100]. A study suggested that LPS treatment in mice contributed to neuroinflammation, cognitive impairment and sickness behavior with neuronal loss in the hippocampus and activated microglia. The levels of IL-1 $\beta$, TNF- $\alpha$, nitric oxide, and prostaglandin E2 were increased with the activation of the NF-KB signaling pathway [101]. Thingore et al. [102] reported that LPS administration enhanced neuroinflammation and contributed to oxidative stress through a decrease in reduced glutathione, superoxide dismutase, and increases in lipid peroxidation in the brains of mice. Treatment with 2,4,6-trinitrobenzenesulfonic acid in mice caused colitis and increased membrane permeability, levels of LPS, Enterobacteriaceae (including Escherichia coli) with a decrease in Lactobacillus johnsonii in the GM composition, activated NF-KB and TNF- $\alpha$, and displayed cognitive impairment. On the other hand, treatment with Lactobacillus johnsonii restored the GM dysbiosis, levels of LPS in the blood, memory and cognitive impairment [103]. Thus, bacterial LPS and amyloids contribute to the hallmarks of AD through MGBX and restoration of GM homeostasis could be beneficial for treating AD.

\section{Potential Therapeutic Strategies for AD}

\subsection{Diet and Food Components}

Different epidemiological studies suggest a strong correlation among lifestyle-related factors, diet, and the onset and consolidation of AD and other kinds of dementia [13]. Studies have reported that nutritional interventions might be helpful to mitigate or delay the risk of cognitive impairment, $\mathrm{AD}$ and other non-psychiatric comorbidities. Fieldhouse et al. [104] stated that a suboptimal diet is related to severely impaired cognition, attributed to low vegetable consumption and is pronounced in AD and dementia. Intake of a diet rich in probiotics, plant-based foods, polyphenols, vitamins, antioxidants, and $\omega-3$ polyunsaturated fatty acids can delay AD [105], as diet can shape host-associated GM composition [106]. Additionally, low intake of saturated fats, refined sugars, and animalderived proteins is also considered beneficial in this regard [105]. Moreover, healthy dietary patterns can be beneficial for cognitive health and can show neuroprotective properties. The Mediterranean diet is deemed beneficial for AD patients as it is rich in many components such as legumes, fruits, vegetables, cereals, polyphenols, non-digestible carbohydrates, and unsaturated fatty acids [107]. Polyphenols (PPs) are naturally occurring bioactive compounds and the most abundant forms of antioxidants in the human diet [63]. PPs have been recognized as potent agents that can lower the risk of AD [13]. Furthermore, vitamins have a positive effect on $\mathrm{AD}$ due to their role in preventing oxidative stress and inflammation that would otherwise lead to $\mathrm{A} \beta$ and tau phosphorylation $[108,109]$. 
The gut microbiome can produce vitamins that are necessary for brain health (including vitamin B6, B9, B12, etc.) [97]. Park et al. [110] exhibited that deficiencies of folate and vitamin $B 12$ are associated with impaired memory function and hippocampal insulin signaling in $\mathrm{AD}$ rats. Thus, supplementation of vitamins (such as vitamin $\mathrm{B}$ complex) may also be helpful in delineating a treatment of AD. Prebiotics promote the growth of beneficial bacteria (including lactobacillus and bifidobacteria), and improve dysbiosis and the associated inflammatory conditions that may ameliorate cognitive impairment [111]. Conversely, the Western diet, consisting of saturated and high trans-fat, high sugar with fewer vegetables and fruits is considered a nutrient-imbalanced diet pattern [107]. This diet may cause metabolic syndromes and diseases and can increase the chances of $\mathrm{AD}$ development. A recent study by Gabriel et al. [112] stated that chronic exposure of a high-fat, high-sugar Western diet to C57BL/6N mice significantly contributed to obesity and memory impairment. These dietary patterns increase the abundance of Flavobacterium, Runella, and Flectobacillus that can activate inflammatory responses by regulating IL-1 $\beta$ and the NF-kB pathways [113]. Ye et al. [114] reported that diets with high-fat can affect the gut-brain axis in zebrafish and that this could be due to modulation of the GM. For example, the abundance of Acinetobacter is $<0.1 \%$ of the total GM in normal conditions and it is associated with inflammatory responses in the gut. However, diets with high-fat content can enhance its abundance by 100-fold [115], which may lead to LPS production and neuroinflammation.

On the other hand, melatonin (a hormone produced by the pineal gland) can prevent or slow down the progression of $\mathrm{AD}$. Melatonin has the potential to enhance $\mathrm{A} \beta$ clearance through glymphatic-lymphatic drainage, blood-brain barrier transportation and degradation pathways, and ameliorates $\mathrm{A} \beta$-induced neurotoxicity [116]. It has been stated that melatonin controls the GM, and its treatment can increase the ratio of Firmicutes to Bacteroidetes and Akkermania [117] and decrease the pathogenic bacteria in gut [118]. Melatonin levels were observed to be lower in AD subjects as compared to healthy aged subjects. Thus, supplementation of melatonin can exert neuroprotective effects on the brain. Additionally, administration of melatonin can reduce $A \beta$ plaques and enhance cognitive performance [116]. The role of diet and other food components in AD is demonstrated in Table 3. 
Table 3. Role of diet and other food components in AD related to gut microbiome.

\begin{tabular}{|c|c|c|c|}
\hline Intervention & Study & Findings & Reference \\
\hline MMKD & $\begin{array}{l}\text { Human } \\
(n=17)\end{array}$ & $\begin{array}{l}\text { MMKD } \uparrow \text { Abundance of Erysipelotriaceae, Slackia, Enterobacteriaceae, Christensenellaceae, and Akkermansia while } \downarrow \\
\text { abundance of Bifidobacterium and Lachnobacterium in subjects. Fecal butyrate and propionate negatively correlated } \\
\text { with } \mathrm{A} \beta_{42} \text {, while Proteobacteria positively correlated with } \mathrm{A} \beta_{42}: \mathrm{A} \beta_{40} \text { in patients with MCI and AD. MMKD slightly } \\
\text { decreased fecal acetate and lactate and increased butyrate and propionate. }\end{array}$ & [119] \\
\hline MMKD & $\begin{array}{l}\text { Human } \\
(n=17)\end{array}$ & $\begin{array}{l}\uparrow \text { proportion of families Togniniaceae, Phaffomyceteceae, Cystofilobasidiaceae, Sclerotiniaceae, Trichocomaceae, and genera } \\
\text { Kazachstania, Botrytis, Cladosporium, and Phaeoacremonium while } \downarrow \text { Meyerozyma in patients with MCI. Fungal taxa showed } \\
\text { distinct correlation arrays with AD markers. MMKD } \uparrow M r a k i a \text { and Agaricus while } \downarrow \text { Claviceps and Saccharomyces. }\end{array}$ & [120] \\
\hline Curcumin & $\begin{array}{l}\text { APP / PS1 double transgenic mice } \\
\qquad(n=15)\end{array}$ & $\begin{array}{l}\text { Curcumin administration altered the abundance of Rikenellaceae, Bacteroidaceae, Lactobacillaceae, and Prevotellaceae at } \\
\text { family level, and Parabacteroides, Bacteroides, and Prevotella at genus level (many of them are considered to be } \\
\text { associated with AD development). Moreover, curcumin intervention decreased A } \beta \text { plaque formation, enhanced } \\
\text { memory abilities and spatial learning. Metabolites of curcumin are also reported to exhibit neuroprotective ability. }\end{array}$ & [121] \\
\hline Q3G & $\begin{array}{l}\text { C57BL/6J mice } \\
\quad(n=30)\end{array}$ & $\begin{array}{l}\text { Q3G administration restored } A \beta_{1-42} \text {-induced cognitive impairment, GM dysbiosis and reduced SCFA production. } \\
\text { Ameliorated Tau phosphorylation and } A \beta \text { accumulation, restored cAMP response element-binding protein and } \\
\text { BDNF levels in the hippocampus. }\end{array}$ & [122] \\
\hline EGCG & $\begin{array}{l}\text { C57BL/ } 6 \text { wild-type and APP/PS1 } \\
\text { mice }(n=30)\end{array}$ & $\begin{array}{l}\text { Treatment with EGCG improves the peripheral parameters like liver insulin pathway signaling, and central memory } \\
\text { deficits. It increased cAMP response element binding phosphorylation rates and synaptic markers. Additionally, } \\
\text { EGCG significantly reduced A } \beta \text { formation and plaque by enhancing the levels of } \alpha \text {-secretase in brain and reduced } \\
\text { neuroinflammation. }\end{array}$ & [123] \\
\hline $\begin{array}{l}\text { Palmitoylethanolamide } \\
\text { and luteolin }\end{array}$ & Sprague Dawley rat & $\begin{array}{l}\text { Prevented the A } \beta \text {-induced microgliosis and astrogliosis, and upregulated the gene expression of pro-inflammatory } \\
\text { cytokines and enzymes. Additionally, it prevented the reduction in GDNF and BDNF mRNA levels. }\end{array}$ & [124] \\
\hline$\omega-3$ Fatty Acid & $\begin{array}{l}\text { Human } \\
(n=174)\end{array}$ & Higher $\omega-3$ fatty acid plasma levels were related to the lower rate of cognitive deterioration. & [125] \\
\hline Xylooligosaccharides & APP/PS1 mice & $\begin{array}{l}\text { Effectively decreased GM alteration and cognitive dysfunction attenuated inflammatory responses and ameliorated } \\
\text { the tight junction barrier in the hippocampus and intestine. }\end{array}$ & [126] \\
\hline FOS & APP/PS1 mice & $\begin{array}{l}\text { Ameliorated pathological changes and cognitive deficits, upregulated the expression levels of synapsin I and } \\
\text { postsynaptic density protein 95, and decreased the phosphorylated level of c-Jun N-terminal kinase. Additionally, } \\
\text { FOS administration reversed the altered GM density. }\end{array}$ & [127] \\
\hline Inulin & $\begin{array}{l}\text { ApoE3 (E3FAD) and ApoE4 } \\
\quad(\text { E4FAD) mice }(n=17)\end{array}$ & $\begin{array}{l}\uparrow \text { Beneficial GM, acetate, propionate, and butyrate in blood and cecum, energy production and blood metabolites in } \\
\text { citric acid cycle and pentose phosphate pathway that support nucleic acid and nucleotide biosynthesis; } \downarrow \text { the } \\
\text { pro-inflammatory rate in the context of reduced } \alpha \text {-diversity in E4FAD-inulin mice. }\end{array}$ & [128] \\
\hline
\end{tabular}

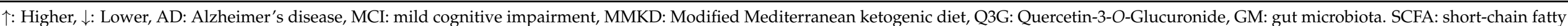

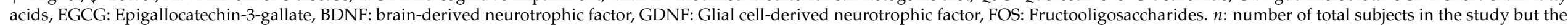
column of findings is only showing the data of diseased ones. 


\subsection{Probiotics}

Probiotics are microorganisms present in the human gut and when supplied in adequate quantities confer health benefits to the host [129]. Diet-based interventions include administration of probiotics through specific supplements, supplementation with PPs, probiotic enriched foods, consumption of dietary fiber, and foods rich in prebiotics [130]. Probiotics can secrete and produce bacterio-toxins (such as bacteriocins) which can suppress bacterial invasion and block pathogen adhesion to epithelial cells [131]. Probiotics compete with pathogenic bacteria for nutrients and binding sites [132]. Additionally, they increase the integrity of the barrier and mucus production by exerting a trophic effect on intestinal mucosa and effects on epithelial cell cytokine secretion $[33,133]$. Oral bacteriotherapy with probiotics has been recently identified to treat and prevent many pathologies [134,135]. A systematic review suggested that preliminary animal studies support the potential role of probiotics in improving cognitive functioning, possibly by decreasing the levels of oxidative and inflammatory biomarkers in MCI or AD; Lactobacillus and Bifidobacterium strains could be the most promising candidates (Table 4). Additionally, the effectiveness of probiotics administration could be affected by dosage, the proportion of each strain, severity of patients and so forth [129].

\subsection{Fecal Microbiota Transplantation}

Fecal microbiota transplantation (FMT) is being studied as a potential intervention for many conditions [136]. FMT is the process of transferring prescreened stool into the GIT of patients to restore the function and increase the overall diversity of GM [137]. Fecal material is expected to be from a highly organized stool bank and administrated through colonoscopy, enema, or capsule [138]. At present, FMT is widely accepted for the treatment of Clostridium difficile infections, however, trials related to human diseases such as cancer, neurodegenerative diseases, and inflammatory bowel disease to metabolic diseases are still ongoing worldwide. FMT could be beneficial for cognitive impairment and decreasing $\mathrm{A} \beta$ plaques in $\mathrm{AD}$ animals' brains [139]. However, studies suggest that caution should be taken in the premature extrapolation of data from preclinical studies because of the inherent limitations of rodent models. Standardization, stool bank services and management, safety assessment, etc., have still not been significantly upgraded, causing complex challenges for regulators and clinicians. Stool availability, adverse effects, and poorly or undefined mechanisms of action are the major concerns related to FMT [11]. Additionally, Sood et al. [140] documented that FMT safety with other routes of administration, patient acceptance, and tolerability must be assessed before recommending this method as the most appropriate way to administer FMT (Table 4). 
Table 4. Use of probiotics and FMT to modify the GM in AD and related findings.

\begin{tabular}{|c|c|c|c|}
\hline Intervention & Study & Findings & Reference \\
\hline $\begin{array}{l}\text { Lactobacillus plantarum C29-fermented } \\
\text { soybean (DW2009) }\end{array}$ & Human $(n=100)$ & $\begin{array}{l}\text { Administration of DW2009 enhanced the serum BDNF levels that may significantly improve } \\
\text { cognitive and memory functions. }\end{array}$ & [141] \\
\hline VSL\#3 & $A P P^{N L-G-F}$ mice & $\begin{array}{l}\text { Increased in the serum SCFA (lactate, acetate, butyrate, propionate, and isobutyrate). Both } \\
\text { serum and brain levels of acetate and lactate in mice correlated with increased expression of the } \\
\text { neuronal activity marker. }\end{array}$ & [142] \\
\hline SLAB51 & 3xTg-AD mice & $\begin{array}{l}\text { Oral administration ameliorated glucose uptake by restoring the brain expression levels of } \\
\text { GLUT1 and GLUT3, and IGF receptor } \beta \text {, in accordance with reduced phosphorylation of AMPK } \\
\text { and Akt. Additionally, decreased phosphorylated tau aggregates and increased glycated } \\
\text { hemoglobin and the accumulation of advanced glycation end products in mice and improved } \\
\text { memory. }\end{array}$ & [143] \\
\hline Bifidobacterium longum (NK46) & 5xFAD-transgenic mice & $\begin{array}{l}\text { Oral administration ameliorated GM composition, decreased blood and fecal LPS levels, } \\
\text { increased tight junction protein expression in the colon and suppressed TNF- } \alpha \text { expression and } \\
\text { NF- } \mathrm{B} \text { B activation. Additionally, decreased the cognitive decline, } \beta / \gamma \text {-secretases, A } \beta \\
\text { accumulation, and caspase- } 3 \text { expression in the hippocampus of mice. }\end{array}$ & [144] \\
\hline Clostridium butyricum & APP/PS1 transgenic mice & $\begin{array}{l}\text { Treatment restored the GM impairment and butyrate. It prevented } A \beta \text { accumulation, cognitive } \\
\text { impairment, production of TNF- } \alpha, \text { IL- } 1 \beta \text {, and microglia activation. }\end{array}$ & [145] \\
\hline Bifidobacterium breve A1 (MCC1274) & Human $(n=79)$ & $\begin{array}{l}\text { Probiotic treatment improved the visuospatial/constructional, immediate memory, and delayed } \\
\text { memory. }\end{array}$ & [146] \\
\hline 5 Lactobacillus and 5 Enterococcus strains & C57BL/6J male mice & $\begin{array}{l}\text { Reduction in leaky gut by increasing tight junctions, and decreasing inflammation. This study } \\
\text { concluded that probiotics could prevent or treat aging-related leaky gut and inflammation that } \\
\text { leads to AD. }\end{array}$ & [147] \\
\hline Lactobacillus plantarum ATCC 8014 & APP/PS1 mice & $\begin{array}{l}\text { Decreased } A \beta \text { levels in the hippocampus, ameliorated cognitive deterioration and protected } \\
\text { neuronal integrity and plasticity }\end{array}$ & [148] \\
\hline Bacteroides thetaiotaomicron & APP/PS1TG mice & Decreased $A \beta$ levels in the hippocampus and significantly improved memory function. & [149] \\
\hline Multispecies probiotics & Human $(n=23)$ & $\begin{array}{l}\text { Decreased the inflammation-causing bacteria and fecal zonulin concentrations, and enhanced } \\
\text { serum kynurenine concentrations. }\end{array}$ & [150] \\
\hline
\end{tabular}


Table 4. Cont.

Intervention Study

ADLPAPT transgenic mice

\section{Findings}

Reference

Mice showed reductions in chronic intestinal and systemic inflammation and loss of epithelia

barrier integrity. FMT ameliorated the formation of glial reactivity, neurofibrillary tangles, A $\beta$

plaques, and cognitive impairment. Additionally, abnormalities in intestinal macrophage activity were also reversed.

Increase in synaptic plasticity, synapsin I expression, decrease in $A \beta_{40-42}$, tau protein

FMT

APPswe/PSEN1dE9 transgenic mice

phosphorylation, COX-2 and CD11b levels were observed after FMT. It also restored GM impairment and short-chain fatty acids levels.

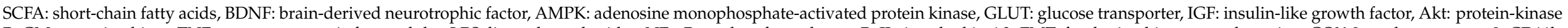

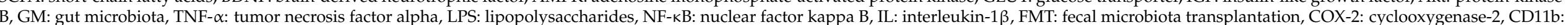

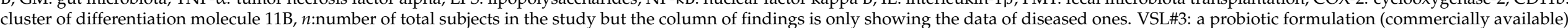

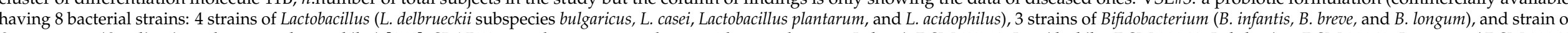

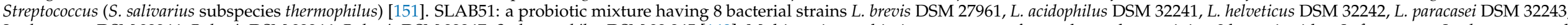

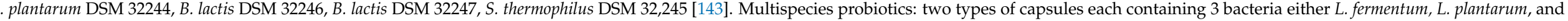

B. lactis, or L. acidophilus, B. bifidum, and B. longum. 


\section{Techniques to Characterize the GM}

Several techniques are currently being used to understand the role of GM in both inducing and preventing specific pathological conditions. The 16S rRNA sequencing method represents the mainstay in terms of a regular and standardized approach to evaluating the composition of human microbiome taxa species down to the genus level [152]. However, next-generation sequencing technologies such as Ion Torrent, Illumina sequencing, and Roche 454 pyrosequencing can identify species composition using shorter DNA stretches with a higher sequence coverage [153]. Computational approaches to identify the 16S rRNA sequencing of disease or non-disease causing microbes have also been developed to better evaluate the biology of the GM community [154]. On the other hand, using 16S rRNA sequencing makes it challenging to understand the genomic information of species with low abundance. Thus, recent studies have been shifting towards the use of high-throughput data techniques for obtaining quantitative and qualitative information of metabolites, DNA, mRNA transcripts, and proteins of the microbial groups in the microbiome [152]. Shotgun metagenomic sequencing helps analyze the whole genomic DNA of bacteria to understand and identify the functional potential of microbial genes [155]. Additionally, meta-omic approaches can be helpful in providing a comprehensive functional view of microorganisms and their role within the microbiome [156]. The HMP Unified Metabolic Analysis Network is another example that can perform functional and metabolic reconstructions of metagenomic data [157]. Although high-throughput next-generation sequencing methods are advantageous, they are also expensive and complex.

\section{Limitations and Future Perspectives}

Most of the animal studies cite here, explored the possible interaction between GM composition and cognitive function. However, human studies were performed on subjects with an established diagnosis of dementia, and outside the geriatric constructs of MCI and cognitive frailty. Thus, a substantial gap exists between the interventional and observational studies performed in animal models of AD. Additionally most of the clinical studies have been conducted with small samples, which is why comprehensive profiling of GM composition and functionality is lacking. Longitudinal studies of high-risk populations are required to examine temporal changes in the GM, as direction of causality cannot be based via cross-sectional studies. Implementation of neuroimaging variables and blood biomarkers as secondary outcomes can enable us to better understand the GM and cognitive functioning.

GM metabolites may affect the host cellular pathways involved in differentiation, maturation, and proliferation functions [33]. Well-defined methodological standards are needed to compare the studies, and other variables such as drugs, concomitant pathologies, and diet must be carefully considered in analyses [158]. Many studies related to uncovering the role of the GM in AD are limited by the fact that only the 16S rRNA sequencing method is being used, providing data on taxa down to the genus level. Because of this, important associations at the strain or species level may be lost. Identifying and characterizing the role of specific microbiomes should be a primary focus of MGBX research. The use of highthroughput next generation sequencing methods for metagenomics, metabolomics, and informatics will be helpful in managing the databases deriving from ongoing GM studies. However, successful results depend on the treatment, disease stage, proper combination of nutrients and bacterial strains [130]. Diet, probiotics and FMT are considered to represent potential therapeutics for $\mathrm{AD}, \mathrm{MCI}$, and other neurodegenerative diseases. However, there are still limitations, especially in probiotic and FMT interventions. Cox et al. [159] stated that caloric restriction experiments exhibited that Lactobacillus and Faecalibaculum genera protected mice from the development of $A \beta$ plaques, while the Lachnospiraceae family and Bacteroides genus were associated with higher $A \beta$ levels in the brain. However, these findings are only apparent in female mice, not male mice; thus, further studies are needed to explore this issue. Other factors such as sex may significantly impact GM links to neurodegeneration. Halverson et al. [12] concluded that not all studies have shown 
effective therapeutic responses because studies have used different treatment methods, study conditions, times of treatments, dosages, and probiotic strains. Therefore, research is needed to better understand the underlying mechanisms, specific procedures, and guidelines to enhance the effectiveness of GM modulation.

\section{Conclusions}

Evolving evidence from animal and human studies suggests that dysbiosis affects the GIT and its related diseases and can also contribute to neurodegeneration due to the fact that the gut communicates with the brain through the gut-brain axis. The GM can produce neurotransmitters that can influence the relations hip between the neurochemistry of the brain and brain disorders such as mood, cognition, behavior, etc. Interestingly, the fungal taxa of the GM with gut bacteria also correlates with AD markers [120]. Diet, probiotics, and FMT administration can modulate the GM composition, alleviating the pathological changes associated with AD. From the safety point of view, diet is one of the most suitable interventions to modulate dysbiosis, but more research is required in this area before application in clinical practice. Thus, further studies are required to understand the specific effects of these therapeutics in the prevention or alleviation of AD.

Author Contributions: Writing—original draft, writing—review and editing, conceptualizationU.S.; writing—review and editing-M.S.A., A.S.; supervision, conceptualization-D.-H.O. All authors have read and agreed to the published version of the manuscript.

Funding: This work was supported by a grant from the Brain Korea (BK) 21 Plus Project (Grant No. 22A20153713433) funded by the Korean Government, Republic of Korea.

Institutional Review Board Statement: Not applicable.

Informed Consent Statement: Not applicable.

Data Availability Statement: No new data were created or analyzed in this study. Data sharing is not applicable to this article.

Conflicts of Interest: The authors declare no conflict of interest.

$\begin{array}{ll}\text { Abbreviations } \\ \text { 5-HT } & \text { 5-hydroxytryptamine } \\ \text { ACTH } & \text { Adrenocorticotropic hormone } \\ \text { AD } & \text { Alzheimer's disease } \\ \text { Akt } & \text { Protein-kinase B } \\ \text { AMPK } & \text { Adenosine monophosphate-activated protein kinase } \\ \text { A } \beta & \text { Amyloid beta } \\ \text { BBB } & \text { Blood-brain barrier } \\ \text { BDNF } & \text { Brain-derived neurotrophic factor } \\ \text { CD11b } & \text { Cluster of differentiation molecule 11B } \\ \text { CNS } & \text { Central nervous system } \\ \text { COX-2 } & \text { Cyclooxygenase-2 } \\ \text { CRF } & \text { Corticotropin-releasing factor } \\ \text { CXCL2 } & \text { C-X-C motif chemokine ligand 2 } \\ \text { EGCG } & \text { Epigallocatechin-3-gallate } \\ \text { FMT } & \text { Fecal microbiota transplantation } \\ \text { FOS } & \text { Fructooligosaccharides } \\ \text { GABA } & \text { gama-aminobutyric acid } \\ \text { GDNF } & \text { Glial cell-derived neurotrophic factor } \\ \text { GIT } & \text { Gastrointestinal tract } \\ \text { GLUT } & \text { Glucose transporter } \\ \text { GM } & \text { Gut microbiota } \\ \text { HPA axis } & \text { Hypothalamic-pituitary-adrenal axis } \\ \text { IGF } & \text { Insulin-like growth factor } \\ \text { IL } & \text { Interleukin } \\ & \end{array}$




$\begin{array}{ll}\text { LPS } & \text { Lipopolysaccharides } \\ \text { MCI } & \text { Mild cognitive impairment } \\ \text { MGBX } & \text { Microbiota-gut-brain axis } \\ \text { MMKD } & \text { Modified Mediterranean ketogenic diet } \\ \text { NF-KB } & \text { Nuclear factor kappa B } \\ \text { NLRP3 } & \text { Nod-like receptor protein } 3 \\ \text { PPG } & \text { Peptidoglycans } \\ \text { PPs } & \text { Polyphenols } \\ \text { Q3G } & \text { Quercetin-3-o-glucuronide } \\ \text { SCFA } & \text { Short-chain fatty acids } \\ \text { TNF- } \alpha & \text { Tumor necrosis factor- } \alpha\end{array}$

\section{References}

1. De JR De-Paula, V.; Forlenza, A.S.; Forlenza, O.V. Relevance of gutmicrobiota in cognition, behaviour and Alzheimer's disease. Pharmacol. Res. 2018, 136, 29-34. [CrossRef]

2. Kumar Singh, A.; Cabral, C.; Kumar, R.; Ganguly, R.; Kumar Rana, H.; Gupta, A.; Rosaria Lauro, M.; Carbone, C.; Reis, F.; Pandey, A.K. Beneficial effects of dietary polyphenols on gut microbiota and strategies to improve delivery efficiency. Nutrients 2019, 11, 2216. [CrossRef]

3. Kesika, P.; Suganthy, N.; Sivamaruthi, B.S.; Chaiyasut, C. Role of gut-brain axis, gut microbial composition, and probiotic intervention in Alzheimer's disease. Life Sci. 2021, 118627. [CrossRef] [PubMed]

4. Fan, Y.; Pedersen, O. Gut microbiota in human metabolic health and disease. Nat. Rev. Microbiol. 2020, 19, 55-71. [CrossRef] [PubMed]

5. Sekirov, I.; Russell, S.L.; Antunes, L.C.M.; Finlay, B.B. Gut microbiota in health and disease. Physiol. Rev. 2010, 90, 859-904 [CrossRef] [PubMed]

6. Dahiya, D.K.; Puniya, M.; Shandilya, U.K.; Dhewa, T.; Kumar, N.; Kumar, S.; Puniya, A.K.; Shukla, P. Gut microbiota modulation and its relationship with obesity using prebiotic fibers and probiotics: A review. Front. Microbiol. 2017, 8, 563. [CrossRef] [PubMed]

7. Etxeberria, U.; Fernández-Quintela, A.; Milagro, F.I.; Aguirre, L.; Martínez, J.A.; Portillo, M.P. Impact of polyphenols and polyphenol-rich dietary sources on gut microbiota composition. J. Agric. Food Chem. 2013, 61, 9517-9533. [CrossRef] [PubMed]

8. Westfall, S.; Lomis, N.; Kahouli, I.; Dia, S.Y.; Singh, S.P.; Prakash, S. Microbiome, probiotics and neurodegenerative diseases: Deciphering the gut brain axis. Cell. Mol. Life Sci. 2017, 74, 3769-3787. [CrossRef]

9. Doifode, T.; Giridharan, V.V.; Generoso, J.S.; Bhatti, G.; Collodel, A.; Schulz, P.E.; Forlenza, O.V.; Barichello, T. The impact of the microbiota-gut-brain axis on Alzheimer's disease pathophysiology. Pharmacol. Res. 2021, 105314. [CrossRef] [PubMed]

10. Madan, S.; Mehra, M.R. Gut dysbiosis and heart failure: Navigating the universe within. Eur. J. Heart Fail. 2020, $22,629-637$. [CrossRef] [PubMed]

11. Liu, S.; Gao, J.; Zhu, M.; Liu, K.; Zhang, H.-L. Gut microbiota and dysbiosis in Alzheimer's disease: Implications for pathogenesis and treatment. Mol. Neurobiol. 2020, 57, 5026-5043. [CrossRef]

12. Halverson, T.; Alagiakrishnan, K. Gut microbes in neurocognitive and mental health disorders. Ann. Med. 2020, 52, 423-443. [CrossRef]

13. Shabbir, U.; Rubab, M.; Tyagi, A.; Oh, D.-H. Curcumin and Its Derivatives as Theranostic Agents in Alzheimer's Disease: The Implication of Nanotechnology. Int. J. Mol. Sci. 2020, 22, 196. [CrossRef] [PubMed]

14. Montiel-Castro, A.J.; González-Cervantes, R.M.; Bravo-Ruiseco, G.; Pacheco-López, G. The microbiota-gut-brain axis: Neurobehavioral correlates, health and sociality. Front. Integr. Neurosci. 2013, 7, 70. [CrossRef] [PubMed]

15. Łuc, M.; Misiak, B.; Pawłowski, M.; Stańczykiewicz, B.; Zabłocka, A.; Szcześniak, D.; Pałęga, A.; Rymaszewska, J. Gut microbiota in dementia. Critical review of novel findings and their potential application. Prog. Neuropsychopharmacol. Biol. Psychiatry 2021, 104, 110039. [CrossRef]

16. Spinelli, M.; Fusco, S.; Grassi, C. Brain insulin resistance and hippocampal plasticity: Mechanisms and biomarkers of cognitive decline. Front. Neurosci. 2019, 13, 788. [CrossRef] [PubMed]

17. Liu, R.T.; Rowan-Nash, A.D.; Sheehan, A.E.; Walsh, R.F.; Sanzari, C.M.; Korry, B.J.; Belenky, P. Reductions in anti-inflammatory gut bacteria are associated with depression in a sample of young adults. Brain Behav. Immun. 2020, 88, 308-324. [CrossRef]

18. Liśkiewicz, P.; Kaczmarczyk, M.; Misiak, B.; Wroński, M.; Bąba-Kubiś, A.; Skonieczna-Żydecka, K.; Marlicz, W.; Bieńkowski, P.; Misera, A.; Pełka-Wysiecka, J.; et al. Analysis of gut microbiota and intestinal integrity markers of inpatients with major depressive disorder. Prog. Neuropsychopharmacol. Biol. Psychiatry 2021, 106, 110076. [CrossRef]

19. Madan, A.; Thompson, D.; Fowler, J.C.; Ajami, N.; Salas, R.; Frueh, B.; Bradshaw, M.; Weinstein, B.; Oldham, J.; Petrosino, J. The gut microbiota is associated with psychiatric symptom severity and treatment outcome among individuals with serious mental illness. J. Affect. Disord. 2020, 264, 98-106. [CrossRef]

20. Zhang, X.; Pan, L.-Y.; Zhang, Z.; Zhou, Y.-y.; Jiang, H.-Y.; Ruan, B. Analysis of gut mycobiota in first-episode, drug-naïve Chinese patients with schizophrenia: A pilot study. Behav. Brain Res. 2020, 379, 112374. [CrossRef] 
21. Guo, L.; Xiao, P.; Zhang, X.; Yang, Y.; Yang, M.; Wang, T.; Lu, H.; Tian, H.; Wang, H.; Liu, J. Inulin ameliorates schizophrenia via modulating gut microbiota and anti-inflammation in mice. Food Funct. 2021. [CrossRef]

22. Lu, Q.; Lai, J.; Lu, H.-F.; Ng, C.; Huang, T.; Zhang, H.; Jiang, J.; Hu, J.; Lu, J.; Lu, S.; et al. Gut microbiota in bipolar depression and its relationship to brain function: An advanced exploration. Front. Psychiatry 2019, 10, 784. [CrossRef]

23. Painold, A.; Mörkl, S.; Kashofer, K.; Halwachs, B.; Dalkner, N.; Bengesser, S.; Birner, A.; Fellendorf, F.; Platzer, M.; Queissner, R.; et al. A step ahead: Exploring the gut microbiota in inpatients with bipolar disorder during a depressive episode. Bipolar Disord. 2019, 21, 40-49. [CrossRef]

24. Jiang, H.Y.; Zhang, X.; Yu, Z.H.; Zhang, Z.; Deng, M.; Zhao, J.H.; Ruan, B. Altered gut microbiota profile in patients with generalized anxiety disorder. J. Psychiatr. Res. 2018, 104, 130-136. [CrossRef]

25. Zhou, Q.; Sun, T.; Wu, F.; Li, F.; Liu, Y.; Li, W.; Dai, N.; Tan, L.; Li, T.; Song, Y. Correlation of gut microbiota and neurotransmitters in a rat model of post-traumatic stress disorder. J. Tradit. Chin. Med. Sci. 2020, 7, 375-385. [CrossRef]

26. Bajaj, J.S.; Sikaroodi, M.; Fagan, A.; Heuman, D.; Gilles, H.; Gavis, E.A.; Fuchs, M.; Gonzalez-Maeso, J.; Nizam, S.; Gillevet, P.M. Posttraumatic stress disorder is associated with altered gut microbiota that modulates cognitive performance in veterans with cirrhosis. Am. J. Physiol. Gastrointest. Liver Physiol. 2019, 317, G661-G669. [CrossRef] [PubMed]

27. Turna, J.; Grosman Kaplan, K.; Anglin, R.; Patterson, B.; Soreni, N.; Bercik, P.; Surette, M.G.; Van Ameringen, M. The gut microbiome and inflammation in obsessive-compulsive disorder patients compared to age-and sex-matched controls: A pilot study. Acta Psychiatr. Scand. 2020, 142, 337-347. [CrossRef] [PubMed]

28. Saji, N.; Murotani, K.; Hisada, T.; Kunihiro, T.; Tsuduki, T.; Sugimoto, T.; Kimura, A.; Niida, S.; Toba, K.; Sakurai, T. Relationship between dementia and gut microbiome-associated metabolites: A cross-sectional study in Japan. Sci. Rep. 2020, 10, 8088. [CrossRef] [PubMed]

29. Saji, N.; Niida, S.; Murotani, K.; Hisada, T.; Tsuduki, T.; Sugimoto, T.; Kimura, A.; Toba, K.; Sakurai, T. Analysis of the relationship between the gut microbiome and dementia: A cross-sectional study conducted in Japan. Sci. Rep. 2019, 9, 1008. [CrossRef]

30. Wu, L.; Han, Y.; Zheng, Z.; Peng, G.; Liu, P.; Yue, S.; Zhu, S.; Chen, J.; Lv, H.; Shao, L.; et al. Altered Gut Microbial Metabolites in Amnestic Mild Cognitive Impairment and Alzheimer's Disease: Signals in Host-Microbe Interplay. Nutrients 2021, 13, 228. [CrossRef]

31. Pedersen, H.K.; Forslund, S.K.; Gudmundsdottir, V.; Petersen, A.Ø.; Hildebrand, F.; Hyötyläinen, T.; Nielsen, T.; Hansen, T.; Bork, P.; Ehrlich, S.D.; et al. A computational framework to integrate high-throughput '-omics' datasets for the identification of potential mechanistic links. Nat. Protoc. 2018, 13, 2781-2800. [CrossRef]

32. Fox, M.; Knorr, D.A.; Haptonstall, K.M. Alzheimer's disease and symbiotic microbiota: An evolutionary medicine perspective. Ann. N. Y. Acad. Sci. 2019, 1449, 3-24. [CrossRef]

33. Conte, C.; Sichetti, M.; Traina, G. Gut-Brain Axis: Focus on Neurodegeneration and Mast Cells. Appl. Sci. 2020, 10, 1828. [CrossRef]

34. Strandwitz, P. Neurotransmitter modulation by the gut microbiota. Brain Res. 2018, 1693, 128-133. [CrossRef]

35. Chalazonitis, A.; Rao, M. Enteric nervous system manifestations of neurodegenerative disease. Brain Res. 2018, 1693, 207-213. [CrossRef] [PubMed]

36. Yang, N.J.; Chiu, I.M. Bacterial signaling to the nervous system through toxins and metabolites. J. Mol. Biol. 2017, 429, 587-605. [CrossRef] [PubMed]

37. Quigley, E.M. Microbiota-brain-gut axis and neurodegenerative diseases. Curr. Neurol. Neurosci. Rep. 2017, 17, 94. [CrossRef]

38. Duranti, S.; Ruiz, L.; Lugli, G.A.; Tames, H.; Milani, C.; Mancabelli, L.; Mancino, W.; Longhi, G.; Carnevali, L.; Sgoifo, A.; et al. Bifidobacterium adolescentis as a key member of the human gut microbiota in the production of GABA. Sci. Rep. 2020, $10,14112$. [CrossRef]

39. Yunes, R.; Poluektova, E.; Vasileva, E.; Odorskaya, M.; Marsova, M.; Kovalev, G.; Danilenko, V. A multi-strain potential probiotic formulation of GABA-producing Lactobacillus plantarum 90sk and bifidobacterium adolescentis 150 with antidepressant effects. Probiotics Antimicrob. Proteins 2020, 12, 973-979. [CrossRef]

40. Zaydi, A.; Lew, L.-C.; Hor, Y.-Y.; Jaafar, M.; Chuah, L.-O.; Yap, K.-P.; Azlan, A.; Azzam, G.; Liong, M.-T. Lactobacillus plantarum DR7 improved brain health in aging rats via the serotonin, inflammatory and apoptosis pathways. Benef. Microbes 2020, 11, 753-766. [CrossRef]

41. Yaghoubfar, R.; Behrouzi, A.; Ashrafian, F.; Shahryari, A.; Moradi, H.R.; Choopani, S.; Hadifar, S.; Vaziri, F.; Nojoumi, S.A.; Fateh, A.; et al. Modulation of serotonin signaling/metabolism by Akkermansia muciniphila and its extracellular vesicles through the gut-brain axis in mice. Sci. Rep. 2020, 10, 22119. [CrossRef]

42. Lee, J.; d'Aigle, J.; Atadja, L.; Quaicoe, V.; Honarpisheh, P.; Ganesh, B.P.; Hassan, A.; Graf, J.; Petrosino, J.F.; Putluri, N.; et al. Gut Microbiota-Derived Short-Chain Fatty Acids Promote Post-Stroke Recovery in Aged Mice. Circ. Res. 2020, 127, $453-465$. [CrossRef]

43. Xu, R.; Tan, C.; He, Y.; Wu, Q.; Wang, H.; Yin, J. Dysbiosis of Gut Microbiota and Short-Chain Fatty Acids in Encephalitis: A Chinese Pilot Study. Front. Immunol. 2020, 11, 1994. [CrossRef]

44. Blaak, E.; Canfora, E.; Theis, S.; Frost, G.; Groen, A.; Mithieux, G.; Nauta, A.; Scott, K.; Stahl, B.; van Harsselaar, J.; et al. Short chain fatty acids in human gut and metabolic health. Benef. Microbes 2020, 11, 411-455. [CrossRef] [PubMed] 
45. Liu, G.; Chong, H.X.; Chung, F.Y.L.; Li, Y.; Liong, M.T. Lactobacillus plantarum DR7 Modulated Bowel Movement and Gut Microbiota Associated with Dopamine and Serotonin Pathways in Stressed Adults. Int. J. Mol. Sci. 2020, 21, 4608. [CrossRef] [PubMed]

46. Koutzoumis, D.N.; Vergara, M.; Pino, J.; Buddendorff, J.; Khoshbouei, H.; Mandel, R.J.; Torres, G.E. Alterations of the gut microbiota with antibiotics protects dopamine neuron loss and improve motor deficits in a pharmacological rodent model of Parkinson's disease. Exp. Neurol. 2020, 325, 113159. [CrossRef]

47. Holzer, P.; Farzi, A. Neuropeptides and the microbiota-gut-brain axis. Adv. Exp. Med. Biol. 2014, 195-219. [CrossRef]

48. Barcik, W.; Pugin, B.; Westermann, P.; Perez, N.R.; Ferstl, R.; Wawrzyniak, M.; Smolinska, S.; Jutel, M.; Hessel, E.M.; Michalovich, D.; et al. Histamine-secreting microbes are increased in the gut of adult asthma patients. J. Allergy Clin. Immunol. 2016, 138, 1491-1494.e7. [CrossRef] [PubMed]

49. Blasco, M.P.; Chauhan, A.; Honarpisheh, P.; Ahnstedt, H.; d'Aigle, J.; Ganesan, A.; Ayyaswamy, S.; Blixt, F.; Venable, S.; Major, A.; et al. Age-dependent involvement of gut mast cells and histamine in post-stroke inflammation. J. Neuroinflamm. 2020, 17, 160. [CrossRef] [PubMed]

50. Yamada, Y.; Yoshikawa, T.; Naganuma, F.; Kikkawa, T.; Osumi, N.; Yanai, K. Chronic brain histamine depletion in adult mice induced depression-like behaviours and impaired sleep-wake cycle. Neuropharmacology 2020, 175, 108179. [CrossRef] [PubMed]

51. Chang, C.-H.; Lin, C.-H.; Lane, H.-Y. d-glutamate and Gut Microbiota in Alzheimer's Disease. Int. J. Mol. Sci. 2020, 21, 2676. [CrossRef] [PubMed]

52. Baxter, M.G.; Crimins, J.L. Acetylcholine Receptor Stimulation for Cognitive Enhancement: Better the Devil You Know? Neuron 2018, 98, 1064-1066. [CrossRef] [PubMed]

53. Chen, D.; Yang, X.; Yang, J.; Lai, G.; Yong, T.; Tang, X.; Shuai, O.; Zhou, G.; Xie, Y.; Wu, Q. Prebiotic effect of fructooligosaccharides from Morinda officinalis on Alzheimer's disease in rodent models by targeting the microbiota-gut-brain axis. Front. Aging Neurosci. 2017, 9, 403. [CrossRef]

54. World Health Organization (WHO). Dementia Fact Sheets. Available online: https://www.who.int/news-room/fact-sheets / detail/dementia (accessed on 20 December 2020).

55. Giacomeli, R.; Izoton, J.C.; Dos Santos, R.B.; Boeira, S.P.; Jesse, C.R.; Haas, S.E. Neuroprotective effects of curcumin lipidcore nanocapsules in a model Alzheimer's disease induced by $\beta$-amyloid 1-42 peptide in aged female mice. Brain Res. 2019, 1721, 146325. [CrossRef]

56. Alzheimer's Association (Alzheimer's Disease Report). Alzheimer's Disease Facts and Figures. Available online: https://www. alz.org/alzheimer_s_dementia. (accessed on 20 December 2020).

57. Voulgaropoulou, S.; van Amelsvoort, T.; Prickaerts, J.; Vingerhoets, C. The effect of curcumin on cognition in Alzheimer's disease and healthy aging: A systematic review of pre-clinical and clinical studies. Brain Res. 2019, 1725, 146476. [CrossRef]

58. Kinney, J.W.; Bemiller, S.M.; Murtishaw, A.S.; Leisgang, A.M.; Salazar, A.M.; Lamb, B.T. Inflammation as a central mechanism in Alzheimer's disease. Alzheimer's Dement. Transl. Res. Clin. Interv. 2018, 4, 575-590. [CrossRef]

59. He, Y.; Li, B.; Sun, D.; Chen, S. Gut microbiota: Implications in Alzheimer's disease. J. Clin. Med. 2020, 9, 2042. [CrossRef]

60. Agrawal, I.; Jha, S. Mitochondrial dysfunction and Alzheimer's disease: Role of microglia. Front. Aging Neurosci. 2020, 12, 252. [CrossRef]

61. Palop, J.J.; Mucke, L. Network abnormalities and interneuron dysfunction in Alzheimer disease. Nat. Rev. Neurosci. 2016, 17, 777-792. [CrossRef]

62. Chin, K.-Y.; Chan, C.Y.; Subramaniam, S.; Muhammad, N.; Fairus, A.; Ng, P.Y.; Jamil, N.A.; Abd Aziz, N.; Ima-Nirwana, S.; Mohamed, N. Positive association between metabolic syndrome and bone mineral density among Malaysians. Int. J. Med. Sci. 2020, 17, 2585-2593. [CrossRef] [PubMed]

63. Shabbir, U.; Rubab, M.; Daliri, E.B.-M.; Chelliah, R.; Javed, A.; Oh, D.-H. Curcumin, Quercetin, Catechins and Metabolic Diseases: The Role of Gut Microbiota. Nutrients 2021, 13, 206. [CrossRef] [PubMed]

64. Naia, L.; Carmo, C.; Campesan, S.; Fão, L.; Cotton, V.E.; Valero, J.; Lopes, C.; Rosenstock, T.R.; Giorgini, F.; Rego, A.C. Mitochondrial SIRT3 confers neuroprotection in Huntington's disease by regulation of oxidative challenges and mitochondrial dynamics. Free Radic. Biol. Med. 2020, 163, 163-179. [CrossRef]

65. Dikalova, A.E.; Pandey, A.; Xiao, L.; Arslanbaeva, L.; Sidorova, T.; Lopez, M.G.; Billings, F.T., 4th; Verdin, E.; Auwerx, J.; Harrison, D.G.; et al. Mitochondrial deacetylase Sirt3 reduces vascular dysfunction and hypertension while Sirt3 depletion in essential hypertension is linked to vascular inflammation and oxidative stress. Circ. Res. 2020, 126, 439-452. [CrossRef]

66. Tyagi, A.; Mirita, C.; Taher, N.; Shah, I.; Moeller, E.; Tyagi, A.; Chong, T.; Pugazhenthi, S. Metabolic syndrome exacerbates amyloid pathology in a comorbid Alzheimer's mouse model. Biochim. Biophys. Acta Mol. Basis Dis. 2020, 1866, 165849. [CrossRef] [PubMed]

67. Han, J.; Oh, J.-P.; Yoo, M.; Cui, C.-H.; Jeon, B.-M.; Kim, S.-C.; Han, J.-H. Minor ginsenoside F1 improves memory in APP/PS1 mice. Mol. Brain 2019, 12, 77. [CrossRef]

68. Gupta, S.; Nair, A.; Jhawat, V.; Mustaq, N.; Sharma, A.; Dhanawat, M.; Khan, S.A. Unwinding Complexities of Diabetic Alzheimer by Potent Novel Molecules. Am. J. Alzheimer's Dis. Other Dement. 2020, 35. [CrossRef]

69. Thomas, K.R.; Bangen, K.J.; Weigand, A.J.; Edmonds, E.C.; Sundermann, E.; Wong, C.G.; Eppig, J.; Werhane, M.L.; DelanoWood, L.; Bondi, M.W. Type 2 Diabetes Interacts With Alzheimer Disease Risk Factors to Predict Functional Decline. Alzheimer Dis. Assoc. Disord. 2020, 34, 10-17. [CrossRef] [PubMed] 
70. Ebrahimpour, S.; Zakeri, M.; Esmaeili, A. Crosstalk between Obesity, Diabetes, and Alzheimer's Disease: Introducing quercetin as an effective triple herbal medicine. Ageing Res. Rev. 2020, 101095. [CrossRef]

71. Picone, P.; Di Carlo, M.; Nuzzo, D. Obesity and Alzheimer's disease: Molecular bases. Eur. J. Neurosci. 2020, 52, 3944-3950. [CrossRef] [PubMed]

72. Tabassum, S.; Misrani, A.; Yang, L. Exploiting Common Aspects of Obesity and Alzheimer's Disease. Front. Hum. Neurosci. 2020, 14,602360 .

73. Cuomo, P.; Papaianni, M.; Sansone, C.; Iannelli, A.; Iannelli, D.; Medaglia, C.; Paris, D.; Motta, A.; Capparelli, R. An In Vitro Model to Investigate the Role of Helicobacter Pylori in Type 2 Diabetes, Obesity, Alzheimer's Disease and Cardiometabolic Disease. Int. J. Mol. Sci. 2020, 21, 8369. [CrossRef] [PubMed]

74. Zhu, S.; Jiang, Y.; Xu, K.; Cui, M.; Ye, W.; Zhao, G.; Jin, L.; Chen, X. The progress of gut microbiome research related to brain disorders. J. Neuroinflamm. 2020, 17, 25. [CrossRef]

75. Vogt, N.M.; Kerby, R.L.; Dill-McFarland, K.A.; Harding, S.J.; Merluzzi, A.P.; Johnson, S.C.; Carlsson, C.M.; Asthana, S.; Zetterberg, H.; Blennow, K.; et al. Gut microbiome alterations in Alzheimer's disease. Sci. Rep. 2017, 7, 13537. [CrossRef]

76. Cattaneo, A.; Cattane, N.; Galluzzi, S.; Provasi, S.; Lopizzo, N.; Festari, C.; Ferrari, C.; Guerra, U.P.; Paghera, B.; Muscio, C.; et al. Association of brain amyloidosis with pro-inflammatory gut bacterial taxa and peripheral inflammation markers in cognitively impaired elderly. Neurobiol. Aging 2017, 49, 60-68. [CrossRef] [PubMed]

77. Liu, P.; Wu, L.; Peng, G.; Han, Y.; Tang, R.; Ge, J.; Zhang, L.; Jia, L.; Yue, S.; Zhou, K. Altered microbiomes distinguish Alzheimer's disease from amnestic mild cognitive impairment and health in a Chinese cohort. Brain Behav. Immun. 2019, 80, 633-643. [CrossRef]

78. Lee, L.-H.; Ser, H.-L.; Khan, T.M.; Long, M.; Chan, K.-G.; Goh, B.-H.; Ab Mutalib, N.-S. IDDF2018-ABS-0239 Dissecting the gut and brain: Potential links between gut microbiota in development of Alzheimer's disease? Gut 2018, 67. [CrossRef]

79. Brandscheid, C.; Schuck, F.; Reinhardt, S.; Schäfer, K.-H.; Pietrzik, C.U.; Grimm, M.; Hartmann, T.; Schwiertz, A.; Endres, K. Altered gut microbiome composition and tryptic activity of the 5xFAD Alzheimer's mouse model. J. Alzheimers Dis. 2017, 56, 775-788. [CrossRef]

80. Mottawea, W.; Chiang, C.-K.; Mühlbauer, M.; Starr, A.E.; Butcher, J.; Abujamel, T.; Deeke, S.A.; Brandel, A.; Zhou, H.; Shokralla, S.; et al. Altered intestinal microbiota-host mitochondria crosstalk in new onset Crohn's disease. Nat. Commun. 2016, 7, 13419. [CrossRef]

81. Cerovic, M.; Forloni, G.; Balducci, C. Neuroinflammation and the gut microbiota: Possible alternative therapeutic targets to counteract Alzheimer's disease? Front. Aging Neurosci. 2019, 11, 284. [CrossRef] [PubMed]

82. Chen, C.; Ahn, E.H.; Kang, S.S.; Liu, X.; Alam, A.; Ye, K. Gut dysbiosis contributes to amyloid pathology, associated with $\mathrm{C} / \mathrm{EBP} \beta$ / AEP signaling activation in Alzheimer's disease mouse model. Sci. Adv. 2020, 6, eaba0466. [CrossRef] [PubMed]

83. Li, Z.; Zhu, H.; Guo, Y.; Du, X.; Qin, C. Gut microbiota regulate cognitive deficits and amyloid deposition in a model of Alzheimer's disease. J. Neurochem. 2020, 155, 448-461. [CrossRef] [PubMed]

84. Kim, M.-S.; Kim, Y.; Choi, H.; Kim, W.; Park, S.; Lee, D.; Kim, D.K.; Kim, H.J.; Choi, H.; Hyun, D.-W.; et al. Transfer of a healthy microbiota reduces amyloid and tau pathology in an Alzheimer's disease animal model. Gut 2020, 69, 283-294. [CrossRef] [PubMed]

85. Guo, Y.J.; Pan, W.W.; Liu, S.B.; Shen, Z.F.; Xu, Y.; Hu, L.L. ERK/MAPK signalling pathway and tumorigenesis. Exp. Ther. Med. 2020, 19, 1997-2007. [CrossRef] [PubMed]

86. Sampson, T.R.; Challis, C.; Jain, N.; Moiseyenko, A.; Ladinsky, M.S.; Shastri, G.G.; Thron, T.; Needham, B.D.; Horvath, I.; Debelius, J.W.; et al. A gut bacterial amyloid promotes $\alpha$-synuclein aggregation and motor impairment in mice. Elife 2020, 9 , e53111. [CrossRef]

87. Friedland, R.P.; McMillan, J.D.; Kurlawala, Z. What are the molecular mechanisms by which functional bacterial amyloids influence amyloid beta deposition and neuroinflammation in neurodegenerative disorders? Int. J. Mol. Sci. 2020, $21,1652$. [CrossRef] [PubMed]

88. Friedland, R.P.; Chapman, M.R. The role of microbial amyloid in neurodegeneration. PloS Pathog. 2017, 13, e1006654. [CrossRef]

89. Zhao, Y.; Dua, P.; Lukiw, W. Microbial sources of amyloid and relevance to amyloidogenesis and Alzheimer's disease (AD). J. Alzheimers Dis. Parkinsonism 2015, 5, 177. [PubMed]

90. Zhou, Y.; Smith, D.; Leong, B.J.; Brännström, K.; Almqvist, F.; Chapman, M.R. Promiscuous cross-seeding between bacterial amyloids promotes interspecies biofilms. J. Biol. Chem. 2012, 287, 35092-35103. [CrossRef]

91. Osorio, C.; Kanukuntla, T.; Diaz, E.; Jafri, N.; Cummings, M.; Sfera, A. The post-amyloid era in Alzheimer's disease: Trust your gut feeling. Front. Aging Neurosci. 2019, 11, 143. [CrossRef]

92. Javed, I.; Zhang, Z.; Adamcik, J.; Andrikopoulos, N.; Li, Y.; Otzen, D.E.; Lin, S.; Mezzenga, R.; Davis, T.P.; Ding, F.; et al. Accelerated Amyloid Beta Pathogenesis by Bacterial Amyloid FapC. Adv. Sci. 2020, 7, 2001299. [CrossRef]

93. Yao, Z.; Cary, B.P.; Bingman, C.A.; Wang, C.; Kreitler, D.F.; Satyshur, K.A.; Forest, K.T.; Gellman, S.H. Use of a stereochemical strategy to probe the mechanism of phenol-soluble modulin $\alpha 3$ toxicity. J. Am. Chem. Soc. 2019, 141, 7660-7664. [CrossRef]

94. Kargbo, R.B. PROTAC Compounds Targeting $\alpha$-Synuclein Protein for Treating Neurogenerative Disorders: Alzheimer's and Parkinson's Diseases. ACS Med. Chem. Lett. 2020, 11, 1086-1087. [CrossRef] [PubMed]

95. Lin, T.-L.; Shu, C.-C.; Chen, Y.-M.; Lu, J.-J.; Wu, T.-S.; Lai, W.-F.; Tzeng, C.-M.; Lai, H.-C.; Lu, C.-C. Like cures like: Pharmacological activity of anti-inflammatory lipopolysaccharides from gut microbiome. Front. Pharmacol. 2020, 11, 554. [CrossRef] 
96. Batista, C.R.A.; Gomes, G.F.; Candelario-Jalil, E.; Fiebich, B.L.; de Oliveira, A.C.P. Lipopolysaccharide-induced neuroinflammation as a bridge to understand neurodegeneration. Int. J. Mol. Sci. 2019, 20, 2293. [CrossRef] [PubMed]

97. Khan, M.S.; Ikram, M.; Park, J.S.; Park, T.J.; Kim, M.O. Gut Microbiota, Its Role in Induction of Alzheimer's Disease Pathology, and Possible Therapeutic Interventions: Special Focus on Anthocyanins. Cells 2020, 9, 853. [CrossRef]

98. Zhan, X.; Stamova, B.; Jin, L.-W.; DeCarli, C.; Phinney, B.; Sharp, F.R. Gram-negative bacterial molecules associate with Alzheimer disease pathology. Neurology 2016, 87, 2324-2332. [CrossRef]

99. Zhao, Y.; Cong, L.; Jaber, V.; Lukiw, W.J. Microbiome-derived lipopolysaccharide enriched in the perinuclear region of Alzheimer's disease brain. Front. Immunol. 2017, 8, 1064. [CrossRef] [PubMed]

100. Zhao, Y.; Jaber, V.; Lukiw, W.J. Secretory products of the human GI tract microbiome and their potential impact on Alzheimer's disease (AD): Detection of lipopolysaccharide (LPS) in AD hippocampus. Front. Cell. Infect. Microbiol. 2017, 7, 318. [CrossRef]

101. Zhao, J.; Bi, W.; Xiao, S.; Lan, X.; Cheng, X.; Zhang, J.; Lu, D.; Wei, W.; Wang, Y.; Li, H.; et al. Neuroinflammation induced by lipopolysaccharide causes cognitive impairment in mice. Sci. Rep. 2019, 9, 5790. [CrossRef]

102. Thingore, C.; Kshirsagar, V.; Juvekar, A. Amelioration of oxidative stress and neuroinflammation in lipopolysaccharide-induced memory impairment using Rosmarinic acid in mice. Metab. Brain Dis. 2020, 36, 299-313. [CrossRef]

103. Jang, S.E.; Lim, S.M.; Jeong, J.J.; Jang, H.M.; Lee, H.J.; Han, M.J.; Kim, D.H. Gastrointestinal inflammation by gut microbiota disturbance induces memory impairment in mice. Mucosal Immunol. 2018, 11, 369-379. [CrossRef]

104. Fieldhouse, J.L.; Doorduijn, A.S.; de Leeuw, F.A.; Verhaar, B.J.; Koene, T.; Wesselman, L.M.; de van der Schueren, M.; Visser, M.; van de Rest, O.; Scheltens, P.; et al. A suboptimal diet is associated with poorer cognition: The NUDAD project. Nutrients 2020, 12, 703. [CrossRef] [PubMed]

105. Pistollato, F.; Iglesias, R.C.; Ruiz, R.; Aparicio, S.; Crespo, J.; Lopez, L.D.; Manna, P.P.; Giampieri, F.; Battino, M. Nutritional patterns associated with the maintenance of neurocognitive functions and the risk of dementia and Alzheimer's disease: A focus on human studies. Pharmacol. Res. 2018, 131, 32-43. [CrossRef]

106. Zhang, Z.; Chen, X.; Zhao, J.; Tian, C.; Wei, X.; Li, H.; Lin, W.; Jiang, A.; Feng, R.; Yuan, J.; et al. Effects of a lactulose-rich diet on fecal microbiome and metabolome in pregnant mice. J. Agric. Food Chem. 2019, 67, 7674-7683. [CrossRef] [PubMed]

107. Zhang, M.; Zhao, D.; Zhou, G.; Li, C. Dietary Pattern, Gut Microbiota, and Alzheimer's Disease. J. Agric. Food Chem. 2020, 68, 12800-12809. [CrossRef]

108. Celik, E.; Sanlier, N. Effects of nutrient and bioactive food components on Alzheimer's disease and epigenetic. Crit. Rev. Food Sci. Nutr. 2019, 59, 102-113. [CrossRef]

109. Shabbir, U.; Khalid, S.; Abbas, M.; Suleria, H.A.R. Natural carotenoids: Weapon against life-style-related disorders. In Phytochemicals from Medicinal Plants: Scope, Applications, and Potential Health Claims, 1st ed.; Suleria, H.A.R., Goyal, M.R., Butt, M.S., Eds.; CRC Press: Boca Raton, FL, USA, 2019; pp. 159-178.

110. Park, S.; Kang, S.; Kim, D.S. Folate and vitamin B-12 deficiencies additively impaired memory function and disturbed the gut microbiota in amyloid- $\beta$ infused rats. Int. J. Vitam. Nutr. Res. 2019, 16, 1-13. [CrossRef]

111. Paiva, I.H.R.; Duarte-Silva, E.; Peixoto, C.A. The role of prebiotics in cognition, anxiety, and depression. Eur. Neuropsychopharmacol. 2020, 34, 1-18. [CrossRef] [PubMed]

112. Gabriel, M.O.; Nikou, M.; Akinola, O.B.; Pollak, D.D.; Sideromenos, S. Western diet-induced fear memory impairment is attenuated by 6-shogaol in C57BL/6N mice. Behav. Brain Res. 2020, 380, 112419. [CrossRef]

113. Arias-Jayo, N.; Abecia, L.; Alonso-Sáez, L.; Ramirez-Garcia, A.; Rodriguez, A.; Pardo, M.A. High-fat diet consumption induces microbiota dysbiosis and intestinal inflammation in zebrafish. Microb. Ecol. 2018, 76, 1089-1101. [CrossRef] [PubMed]

114. Ye, L.; Mueller, O.; Bagwell, J.; Bagnat, M.; Liddle, R.A.; Rawls, J.F. High fat diet induces microbiota-dependent silencing of enteroendocrine cells. Elife 2019, 8, e48479. [CrossRef] [PubMed]

115. Zakaria, R.; Wan Yaacob, W.; Othman, Z.; Long, I.; Ahmad, A.; Al-Rahbi, B. Lipopolysaccharide-induced memory impairment in rats: A model of Alzheimer's disease. Physiol. Res. 2017, 66, 553-565. [CrossRef] [PubMed]

116. Li, Y.; Zhang, J.; Wan, J.; Liu, A.; Sun, J. Melatonin regulates A $\beta$ production/clearance balance and A $\beta$ neurotoxicity: A potential therapeutic molecule for Alzheimer's disease. Biomed. Pharmacother. 2020, 132, 110887. [CrossRef]

117. Gao, T.; Wang, Z.; Dong, Y.; Cao, J.; Lin, R.; Wang, X.; Yu, Z.; Chen, Y. Role of melatonin in sleep deprivation-induced intestinal barrier dysfunction in mice. J. Pineal Res. 2019, 67, e12574. [CrossRef]

118. Ren, W.; Wang, P.; Yan, J.; Liu, G.; Zeng, B.; Hussain, T.; Peng, C.; Yin, J.; Li, T.; Wei, H.; et al. Melatonin alleviates weanling stress in mice: Involvement of intestinal microbiota. J. Pineal Res. 2018, 64. [CrossRef]

119. Nagpal, R.; Neth, B.J.; Wang, S.; Craft, S.; Yadav, H. Modified Mediterranean-ketogenic diet modulates gut microbiome and short-chain fatty acids in association with Alzheimer's disease markers in subjects with mild cognitive impairment. EBioMedicine 2019, 47, 529-542. [CrossRef]

120. Nagpal, R.; Neth, B.J.; Wang, S.; Mishra, S.P.; Craft, S.; Yadav, H. Gut mycobiome and its interaction with diet, gut bacteria and alzheimer's disease markers in subjects with mild cognitive impairment: A pilot study. EBioMedicine 2020, 59, 102950. [CrossRef]

121. Sun, Z.-Z.; Li, X.-Y.; Wang, S.; Shen, L.; Ji, H.-F. Bidirectional interactions between curcumin and gut microbiota in transgenic mice with Alzheimer's disease. Appl. Microbiol. Biotechnol. 2020, 104, 3507-3515. [CrossRef]

122. Xu, M.; Huang, H.; Mo, X.; Zhu, Y.; Chen, X.; Li, X.; Peng, X.; Xu, Z.; Chen, L.; Rong, S.; et al. Quercetin-3-O-Glucuronide Alleviates Cognitive Deficit and Toxicity in Aß1-42-Induced AD-Like Mice and SH-SY5Y Cells. Mol. Nutr. Food Res. 2020, e2000660. [CrossRef] 
123. Ettcheto, M.; Cano, A.; Manzine, P.R.; Busquets, O.; Verdaguer, E.; Castro-Torres, R.D.; García, M.L.; Beas-Zarate, C.; Olloquequi, J.; Auladell, C.; et al. Epigallocatechin-3-Gallate (EGCG) Improves Cognitive Deficits Aggravated by an Obesogenic Diet Through Modulation of Unfolded Protein Response in APPswe/PS1dE9 Mice. Mol. Neurobiol. 2020, 57, 1814-1827. [CrossRef]

124. Facchinetti, R.; Valenza, M.; Bronzuoli, M.R.; Menegoni, G.; Ratano, P.; Steardo, L.; Campolongo, P.; Scuderi, C. Looking for a Treatment for the Early Stage of Alzheimer's Disease: Preclinical Evidence with Co-Ultramicronized Palmitoylethanolamide and Luteolin. Int. J. Mol. Sci. 2020, 21, 3802. [CrossRef]

125. Eriksdotter, M.; Vedin, I.; Falahati, F.; Freund-Levi, Y.; Hjorth, E.; Faxen-Irving, G.; Wahlund, L.-O.; Schultzberg, M.; Basun, H.; Cederholm, T. Plasma fatty acid profiles in relation to cognition and gender in Alzheimer's disease patients during oral omega-3 fatty acid supplementation: The omegAD study. J. Alzheimers Dis. 2015, 48, 805-812. [CrossRef]

126. Han, D.; Li, Z.; Liu, T.; Yang, N.; Li, Y.; He, J.; Qian, M.; Kuang, Z.; Zhang, W.; Ni, C.; et al. Prebiotics Regulation of Intestinal Microbiota Attenuates Cognitive Dysfunction Induced by Surgery Stimulation in APP/PS1 Mice. Aging Dis. 2020, 11, 1029-1045. [CrossRef]

127. Sun, J.; Liu, S.; Ling, Z.; Wang, F.; Ling, Y.; Gong, T.; Fang, N.; Ye, S.; Si, J.; Liu, J. Fructooligosaccharides ameliorating cognitive deficits and neurodegeneration in APP/PS1 transgenic mice through modulating gut microbiota. J. Agric. Food Chem. 2019, 67, 3006-3017. [CrossRef]

128. Chang, Y.-H.; Hoffman, J.; Yanckello, L.; McCulloch, S.; Lin, P.; Lane, A.; Chlipala, G.; Green, S.; Lin, A.-L. Apolipoprotein E Genotype-Dependent Nutrigenetic Effects to Prebiotic Inulin for Reducing Risk for Alzheimer's Disease in a Mouse Model. Curr. Dev. Nutr. 2020, 4, 1197. [CrossRef]

129. Den, H.; Dong, X.; Chen, M.; Zou, Z. Efficacy of probiotics on cognition, and biomarkers of inflammation and oxidative stress in adults with Alzheimer's disease or mild cognitive impairment-A meta-analysis of randomized controlled trials. Aging 2020, 12, 4010-4039. [CrossRef]

130. Bonfili, L.; Cecarini, V.; Gogoi, O.; Gong, C.; Cuccioloni, M.; Angeletti, M.; Rossi, G.; Eleuteri, A.M. Microbiota modulation as preventative and therapeutic approach in Alzheimer's disease. FEBS J. 2020. [CrossRef]

131. Cryan, J.F.; O’Riordan, K.J.; Sandhu, K.; Peterson, V.; Dinan, T.G. The gut microbiome in neurological disorders. Lancet Neurol. 2020, 19, 179-194. [CrossRef]

132. Rossi, M.; Amaretti, A.; Raimondi, S. Folate production by probiotic bacteria. Nutrients 2011, 3, 118-134. [CrossRef] [PubMed]

133. Neunlist, M.; Schemann, M. Nutrient-induced changes in the phenotype and function of the enteric nervous system. J. Physiol. 2014, 592, 2959-2965. [CrossRef] [PubMed]

134. Bonfili, L.; Cecarini, V.; Berardi, S.; Scarpona, S.; Suchodolski, J.S.; Nasuti, C.; Fiorini, D.; Boarelli, M.C.; Rossi, G.; Eleuteri, A.M. Microbiota modulation counteracts Alzheimer's disease progression influencing neuronal proteolysis and gut hormones plasma levels. Sci. Rep. 2017, 7, 2426. [CrossRef]

135. Cecarini, V.; Bonfili, L.; Gogoi, O.; Lawrence, S.; Venanzi, F.M.; Azevedo, V.; Mancha-Agresti, P.; Drumond, M.M.; Rossi, G.; Berardi, S.; et al. Neuroprotective effects of p62 (SQSTM1)-engineered lactic acid bacteria in Alzheimer's disease: A pre-clinical study. Aging 2020, 12, 15995-16020. [CrossRef]

136. Carlson, P.E., Jr. Regulatory considerations for fecal microbiota transplantation products. Cell Host Microbe 2020, $27,173-175$. [CrossRef]

137. Allegretti, J.R.; Mullish, B.H.; Kelly, C.; Fischer, M. The evolution of the use of faecal microbiota transplantation and emerging therapeutic indications. Lancet 2019, 394, 420-431. [CrossRef]

138. Mullish, B.H.; Quraishi, M.N.; Segal, J.P.; McCune, V.L.; Baxter, M.; Marsden, G.L.; Moore, D.J.; Colville, A.; Bhala, N.; Iqbal, T.H.; et al. The use of faecal microbiota transplant as treatment for recurrent or refractory Clostridium difficile infection and other potential indications: Joint British Society of Gastroenterology (BSG) and Healthcare Infection Society (HIS) guidelines. Gut 2018, 67, 1920-1941. [CrossRef] [PubMed]

139. Sun, J.; Xu, J.; Ling, Y.; Wang, F.; Gong, T.; Yang, C.; Ye, S.; Ye, K.; Wei, D.; Song, Z.; et al. Fecal microbiota transplantation alleviated Alzheimer's disease-like pathogenesis in APP/PS1 transgenic mice. Transl. Psychiatry 2019, 9, 189. [CrossRef]

140. Sood, A.; Singh, A.; Mahajan, R.; Midha, V.; Mehta, V.; Gupta, Y.K.; Narang, V.; Kaur, K. Acceptability, tolerability, and safety of fecal microbiota transplantation in patients with active ulcerative colitis (AT\&S Study). J. Gastroenterol. Hepatol. 2020, 35, 418-424.

141. Hwang, Y.-H.; Park, S.; Paik, J.-W.; Chae, S.-W.; Kim, D.-H.; Jeong, D.-G.; Ha, E.; Kim, M.; Hong, G.; Park, S.-H.; et al. Efficacy and safety of Lactobacillus plantarum C29-fermented soybean (DW2009) in individuals with mild cognitive impairment: A 12-week, multi-center, randomized, double-blind, placebo-controlled clinical trial. Nutrients 2019, 11, 305. [CrossRef] [PubMed]

142. Kaur, H.; Golovko, S.; Golovko, M.Y.; Singh, S.; Darland, D.C.; Combs, C.K. Effects of Probiotic Supplementation on Short Chain Fatty Acids in the App NL-GF Mouse Model of Alzheimer's Disease. J. Alzheimers Dis. 2020, 76, 1083-1102. [CrossRef] [PubMed]

143. Bonfili, L.; Cecarini, V.; Gogoi, O.; Berardi, S.; Scarpona, S.; Angeletti, M.; Rossi, G.; Eleuteri, A.M. Gut microbiota manipulation through probiotics oral administration restores glucose homeostasis in a mouse model of Alzheimer's disease. Neurobiol. Aging 2020, 87, 35-43. [CrossRef] [PubMed]

144. Lee, H.-J.; Lee, K.-E.; Kim, J.-K.; Kim, D.-H. Suppression of gut dysbiosis by Bifidobacterium longum alleviates cognitive decline in 5XFAD transgenic and aged mice. Sci. Rep. 2019, 9, 11814. [CrossRef]

145. Sun, J.; Xu, J.; Yang, B.; Chen, K.; Kong, Y.; Fang, N.; Gong, T.; Wang, F.; Ling, Z.; Liu, J. Effect of Clostridium butyricum against Microglia-Mediated Neuroinflammation in Alzheimer's Disease via Regulating Gut Microbiota and Metabolites Butyrate. Mol. Nutr. Food Res. 2020, 64, e1900636. [CrossRef] 
146. Xiao, J.; Katsumata, N.; Bernier, F.; Ohno, K.; Yamauchi, Y.; Odamaki, T.; Yoshikawa, K.; Ito, K.; Kaneko, T. Probiotic Bifidobacterium breve in Improving Cognitive Functions of Older Adults with Suspected Mild Cognitive Impairment: A Randomized, Double-Blind, Placebo-Controlled Trial. J. Alzheimers Dis. 2020, 77, 137-147. [CrossRef] [PubMed]

147. Ahmadi, S.; Wang, S.; Nagpal, R.; Wang, B.; Jain, S.; Razazan, A.; Mishra, S.P.; Zhu, X.; Wang, Z.; Kavanagh, K.; et al. A humanorigin probiotic cocktail ameliorates aging-related leaky gut and inflammation via modulating the microbiota/taurine/tight junction axis. JCI Insight 2020, 5, e132055. [CrossRef]

148. Wang, Q.-J.; Shen, Y.-E.; Wang, X.; Fu, S.; Zhang, X.; Zhang, Y.-N.; Wang, R.-T. Concomitant memantine and Lactobacillus plantarum treatment attenuates cognitive impairments in APP/PS1 mice. Aging 2020, 12, 628-649. [CrossRef] [PubMed]

149. Abraham, D.; Feher, J.; Scuderi, G.L.; Szabo, D.; Dobolyi, A.; Cservenak, M.; Juhasz, J.; Ligeti, B.; Pongor, S.; Gomez-Cabrera, M.C.; et al. Exercise and probiotics attenuate the development of Alzheimer's disease in transgenic mice: Role of microbiome. Exp. Gerontol. 2019, 115, 122-131. [CrossRef] [PubMed]

150. Agahi, A.; Hamidi, G.A.; Daneshvar, R.; Hamdieh, M.; Soheili, M.; Alinaghipour, A.; Esmaeili Taba, S.M.; Salami, M. Does severity of Alzheimer's disease contribute to its responsiveness to modifying gut microbiota? A double blind clinical trial. Front. Neurol. 2018, 9, 662. [CrossRef]

151. Cheng, F.-S.; Pan, D.; Chang, B.; Jiang, M.; Sang, L.-X. Probiotic mixture VSL\# 3: An overview of basic and clinical studies in chronic diseases. World J. Clin. Cases 2020, 8, 1361-1384. [PubMed]

152. Johnson, J.S.; Spakowicz, D.J.; Hong, B.-Y.; Petersen, L.M.; Demkowicz, P.; Chen, L.; Leopold, S.R.; Hanson, B.M.; Agresta, H.O.; Gerstein, M. Evaluation of $16 \mathrm{~S}$ rRNA gene sequencing for species and strain-level microbiome analysis. Nat. Commun. 2019, 10, 5029. [CrossRef]

153. Ambardar, S.; Gupta, R.; Trakroo, D.; Lal, R.; Vakhlu, J. High throughput sequencing: An overview of sequencing chemistry. Indian J. Microbiol. 2016, 56, 394-404. [CrossRef] [PubMed]

154. Caporaso, J.G.; Kuczynski, J.; Stombaugh, J.; Bittinger, K.; Bushman, F.D.; Costello, E.K.; Fierer, N.; Pena, A.G.; Goodrich, J.K.; Gordon, J.I.; et al. QIIME allows analysis of high-throughput community sequencing data. Nat. Methods 2010, 7, 335-336. [CrossRef]

155. Yap, M.; Feehily, C.; Walsh, C.J.; Fenelon, M.; Murphy, E.F.; McAuliffe, F.M.; van Sinderen, D.; O’Toole, P.W.; O’Sullivan, O.; Cotter, P.D. Evaluation of methods for the reduction of contaminating host reads when performing shotgun metagenomic sequencing of the milk microbiome. Sci. Rep. 2020, 10, 21665. [CrossRef] [PubMed]

156. Zhang, X.; Li, L.; Butcher, J.; Stintzi, A.; Figeys, D. Advancing functional and translational microbiome research using meta-omics approaches. Microbiome 2019, 7, 154. [CrossRef]

157. Abubucker, S.; Segata, N.; Goll, J.; Schubert, A.M.; Izard, J.; Cantarel, B.L.; Rodriguez-Mueller, B.; Zucker, J.; Thiagarajan, M.; Henrissat, B.; et al. Metabolic reconstruction for metagenomic data and its application to the human microbiome. PLoS Comput. Biol. 2012, 8, e1002358. [CrossRef]

158. Marizzoni, M.; Provasi, S.; Cattaneo, A.; Frisoni, G.B. Microbiota and neurodegenerative diseases. Curr. Opin. Neurol. 2017, 30, 630-638. [CrossRef] [PubMed]

159. Cox, L.M.; Schafer, M.J.; Sohn, J.; Vincentini, J.; Weiner, H.L.; Ginsberg, S.D.; Blaser, M.J. Calorie restriction slows age-related microbiota changes in an Alzheimer's disease model in female mice. Sci. Rep. 2019, 9, 17904. [CrossRef] [PubMed] 